\title{
The Ancient Routes and New Lycian Inscriptions around Fethiye
}

\author{
Fatih ONUR* - Ş. Recai TEKOĞLU**
}

\section{Introduction (F. ONUR)}

Field surveys conducted on the ancient road network in Lycia since they were officially initiated in 2004 have brought new points of view and new materials to better understand Lycian geography and history. ${ }^{1}$ Some of the surveys in 2016, 2017 and 2018, the research reports of which contained some preliminary observations ${ }^{2}$, were concentrated on the county (ilçe) of Fethiye, ancient Telmessos. The area of the Fethiye Plain is ca. 60 square kilometers. The approximate borders extend to Yanıklar to the west, Eldirek to the north, Esenköy (Dont) to the east, and western parts of Fethiye town. Central Fethiye and ancient Telmessos are at the southwestern corner of this plain. According to the Monumentum Patarense (MP), dated to the Early Imperial period, Telmessos's ancient neighbours were Kalynda to the northwest, Kadyanda to the northeast, Tlos to the east and Pinara to the southeast. Between these, the area of the Telmessian territory can be estimated as measuring ca. 300-400 square kilometers under the Early Empire.

The gulf of Fethiye and the settlements around it have been the subject of a well-known study, "Der Golf von Fethiye", authored by Werner Tietz (2003). This book covers the history of the region from the Bronze Age to the end of Roman Imperial Era, and investigates the individual settlements, including Lydai, Lissai, Krya, Kalynda, Daidala, Hippoukome, Oktapolis, Symbra, Telandros and Telmessos. Kadyanda was excluded on the basis that the city was actually oriented towards Xanthos Valley and to the north, ${ }^{3}$ not towards Fethiye Plain. This important observation is relevant also to the discussion of TAM II 127 (see below p. 2), an inscription which raises questions concerning the territories of Kadyanda and Telmessos. Most of the historical and geographical evidence has already been discussed in detail by Tietz. In this paper we will give an

\footnotetext{
* Prof. Dr. Fatih Onur, Akdeniz University, Faculty of Letters, Dept. of Ancient Languages and Cultures, Campus 07058 Antalya (fatihonur@akdeniz.edu.tr; https://orcid.org/0000-0002-8568-0222).

${ }^{* *}$ Prof. Dr. Ş. Recai Tekoğlu, Dokuz Eylül University, Dept. of History, Tinaztepe Campus, 35390 Buca İzmir (recai.tekoglu@deu.edu.tr; https://orcid.org/0000-0002-7702-2625).

This contribution results from the field surveys on the ancient roads of Lycia directed by the late Prof. Sencer Şahin until 2014, by Prof. N. Eda Akyürek Şahin until 2017, and thereafter by Fatih Onur, with permission from the Turkish Ministry of Culture and Tourism. These field surveys have been supported by the Akdeniz University Scientific Research Projects Coordination Unit within the projects (nos. SBA-20161675 and SBA-2019-4823) and by Koç University - Suna \& İnan Kıraç Research Center for Mediterranean Civilisations from 2015 onwards (especially within the project no. KU AKMED 2018/P.1016). This paper also forms a part of F. Onur's project entitled "The spatial conceptualization of power in the Roman empire: Lycia and Rome in the 1st c. A.D.", the funding of which has been provided by the Alexander von Humboldt Foundation.

${ }^{1}$ For detailed information on these field surveys and publications of the results please visit: http://adkam.akdeniz.edu.tr/sp-introduction.
}

${ }^{2}$ Akyürek Şahin et al. 2017, 205-212; Akyürek Şahin et al. 2018, 398-401.

${ }^{3}$ Tietz 2003, 3 . 
account on the ancient road connections and new Lycian inscriptions around Fethiye District based on the field survey results.

\section{The Courses of the Roads (F. ONUR)}

The roads around Fethiye District, which are the subjects of this paper, on Face B of the MP are as follow:

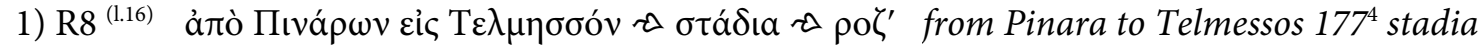

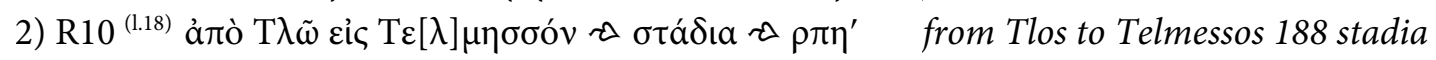

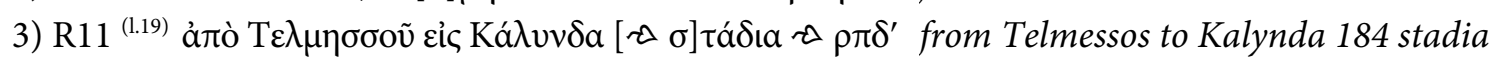

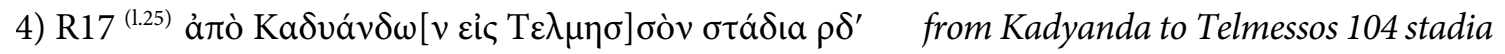

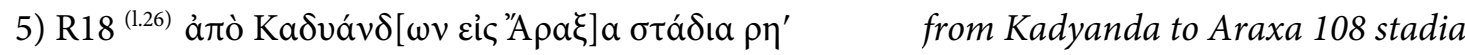

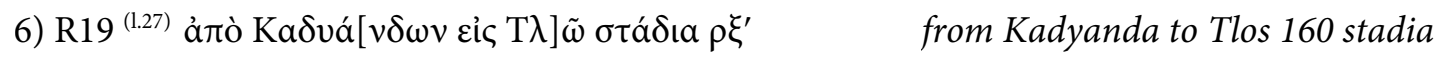

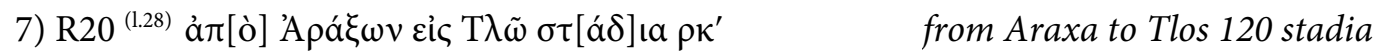

\section{From Pinara to Telmessos (R8), 176 stades, ca. 32,8 km.}

There were two routes between Telmessos and Pinara, one of which is mentioned in the MP, and since this road had no intermediate points, its course should lead only through the territories of these two cities.

a) The route of Minare - Kabaağaç - Gökben - Bozyer - Esenköy (Dont) - Fethiye

This route is today the main road between Fethiye and Kabaağaç, and coincides with the main Kaş-Fethiye road in two directions, one to the east through Alaçat and the other through Minare. This was used also in antiquity, since, the accounts of Benndorf and Niemann indicate that there were remains of ancient road and several ancient ruins in Esenköy (Dont). ${ }^{5}$ There are also several Ottoman cisterns along the way, proving that it has been used until recent times. Davies described this road as the "most frequented road to Makri" at the end of $19^{\text {th }} c .^{6}$ In our surveys, we saw no road remains or ancient ruins, since these seem to have been removed or buried by modern road constructions and building activities. The road's course should have combined with the route from Tlos to Telmessos somewhere near Gökben or Esenköy (Dont). ${ }^{7}$

A funerary inscription recorded in Esenköy (Dont) on this route, today lost, is important for understanding the city territories and road connections in the eastern hinterland of Telmessos (TAM II 127). The inscription was first mentioned by Hoskyn, who reported that it had been found by Daniell. ${ }^{8}$ The text, which was first published by Ross and then by Spratt and Forbes, reads that the tomb belonged to Eutaktos from Kadyanda and fine for violation against the tomb was to be paid to Kadyanda. ${ }^{9}$ If the inscription is in situ, the penalty formula at first glance suggests

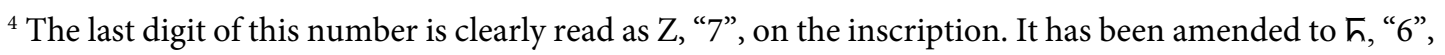
by Şahin 2014, since only 176 can be divided into 8, which then makes 22 Roman miles.

${ }^{5}$ Benndorf - Niemann 1884, 46-47; see also TAM II, 1, 40.

${ }^{6}$ Davies 1895, 104.

${ }^{7}$ Şahin - Adak 2007, 137-138; Şahin 2014, 155.

${ }^{8}$ Hoskyn 1842, 149: "Mr. Fellowes has ascertained it to be the city Cadyanda; an inscription lately found in a Turkish burying-ground on the plain of Makri, by the Rev. E. T. Daniell, and which was probably brought from this place, gives it the same name.”.

${ }^{9}$ Ross 1845, 289-290, no. 4: "In einem Türkischen Gottesacker, am Wege von Makri (Telmessos) nach Pinara; nach einer Abschrift desselben Capitain Graves ... (the inscripton) ... Die Ruinen von Kadyanda, die ich
} 
that the territory of Kadyanda extended up to the land belonging to Esenköy (Dont) located ca. $12 \mathrm{~km}$ to the east of Fethiye. However, since one might expect that the plain of Fethiye was part of the territory of Telmessos in antiquity, some scholars have proposed that a city might have been able to collect fines for tombs located in the territory of other cities, ${ }^{10}$ while others suggest that the inscription was not in its original location. ${ }^{11} \mathrm{~A}$ few exceptional Lycian examples, which present a blurred picture concerning territorial attachment, might support the first hypothesis. ${ }^{12}$ Still, it is more plausible to think that this inscription was actually brought to Esenköy from the southern edges of Kadyandan territory, because the road in the MP runs directly from Tlos to Telmessos, meaning that there was no other city territory between them, and this road has to run close by the inscription's find-spot.

The settlement located at Asarck on this way (Fig. 1-Fig. 4) - ancient Aloanda according to information provided by inscriptions found on the site - is not recorded in the MP. A Lycian inscription found on the site does not give the settlement's name (see below p. 17 no. 1), but the Greek inscriptions show that it had its own ethnicon or demoticon, Aloandeus. ${ }^{13}$ The settlement had a popular assembly in the Hellenistic Period, which awarded a crown to a certain Pokomas. ${ }^{14}$

nicht besucht habe, liegen einige Stunden nordöstlich von dem Platze, wo sich diese Inschrift findet..."; Spratt - Forbes 1847, II, 268: "In a Tur kish burial-ground on the plain of Makri, near the junction of the road from the Dey's Bridge with that from Pinara, at about two hours' journey from Makri, and five or six miles south of Cadyanda"; Benndorf - Niemann 1884, 46 and fn. 4 (description and minor revisions); CIG III. Add. 4208c ("Telmissi, in cemeteiro ad viam quae deducit Pinara"); TAM II 127 ("Ante vicum Dont ad

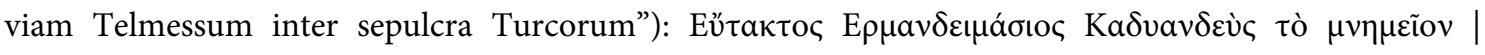

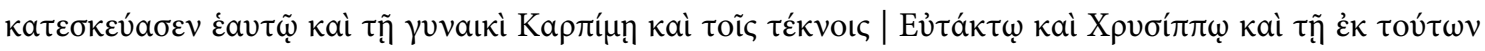

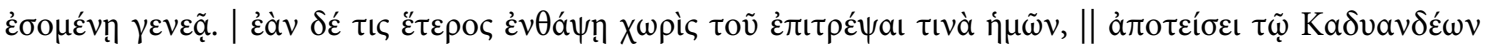
$\delta \eta \dot{\eta} \mu * \varphi^{\prime} . \mid \zeta \tilde{n}$.

${ }^{10}$ Tietz 2003, 337-339.

${ }^{11}$ Şahin - Adak 2007, 162; Şahin 2014, 195.

${ }^{12}$ Some examples: a tomb in Tristomon records that the right of use was purchased from Myran authorities while its fine was paid to Kyaneai, see Walpole 1820, 546 no. IX (copied by Cockerell, incorrectly

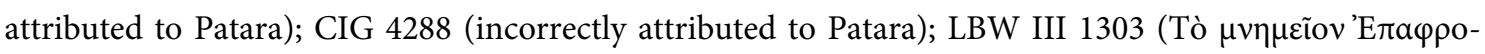

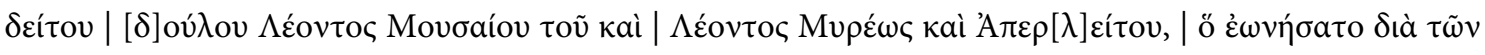

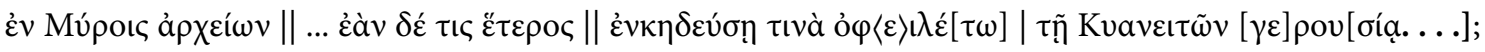
On a sarcophagus found in Bağlica between Phellos and Kyaneai the fine is to be paid to Xanthos, see Barth 1850, 258 no. 40 ("Eine sehr verlöschte Sarkophaginschrift westlich von Sarla:"); CIG III Add. 4278i; Heberdey - Kalinka 1897, 32-33 No. 40; Stemler 1909, 67-68; Bean 1958, 51 with fn. 8 (... $\varepsilon(\grave{i}) \delta \grave{\varepsilon} \mu \eta$,

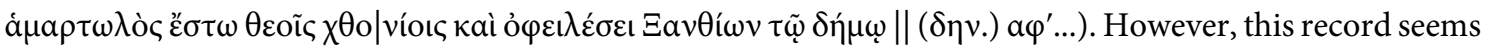
to be incorrect since the sarchophagus mentioned has never been found again at this spot. On a funerary inscription found in Antiphellos, the fine is collected by the demos of Myra and Antiphellos, see Nolle -

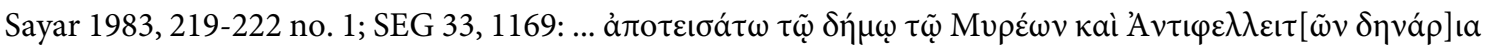

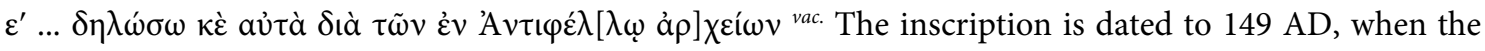
eponym Veranius Tlepolemos was archiereus. The editors conjecture that there may have been a sympolity between Myra and Antiphellos following the earthquake of 141 AD. However the editors of SEG approach this suggestion with suspicion. See also Zimmermann 1992, 142-146.

${ }^{13}$ Davies 1895, 104 no. 9 = TAM II 526.

${ }^{14}$ There are two more Greek inscriptions from Aloanda, which give the same ethnicon and which will be published soon by F. Onur and S. Kılıç-Aslan. 
This may suggest, either that the road recorded in the MP between Pinara and Telmessos in the Early Imperial Period, if not earlier, did not go through Asarcık, but took a different course, or that the site of Aloanda was subordinate either to Telmessos or to Pinara. The answer entirely depends on Aloanda's political status in the time of the MP, a question which is not yet resolved. If Aloanda was a self-governing demos at the time of the MP, the road between Pinara and Telmessos could not have taken the route through Kabaağaç, because in that case the MP should have indicated a road "from Pinara to Telmessos through Aloanda", or two roads "from Pinara to Aloanda" and "from Aloanda to Telmessos". If Aloanda was indeed autonomous, the road mentioned in the MP must have taken another course. On the other hand, there should have been road connections from Aloanda to both Pinara and Telmessos. We observed that there is an ancient path passing through the area between the rock-cut tomb to the west of the site and the hill, on which most of the remains of Aloanda are located (Fig. 5).

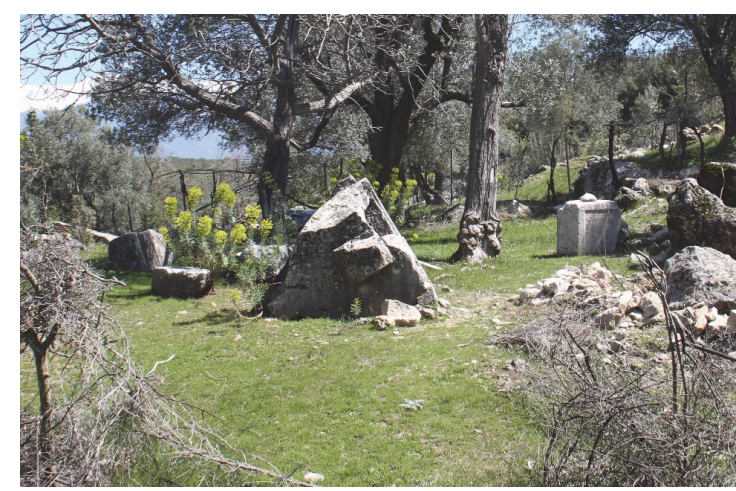

Fig. 1) Funerary remains at Asarcık/Aloanda

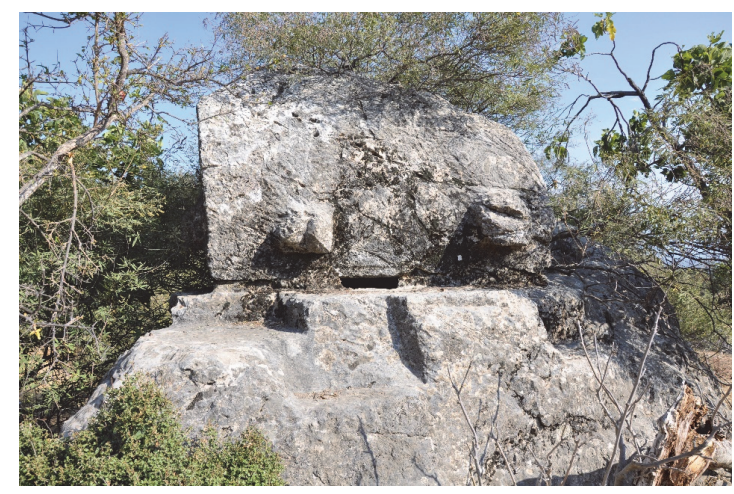

Fig. 3) Funerary remains at Asarck/Aloanda

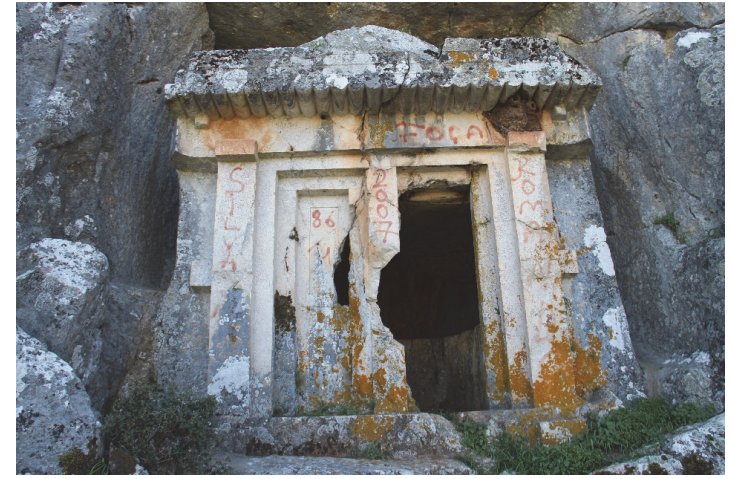

Fig. 2) Rock cut tomb to the east of Asarcık

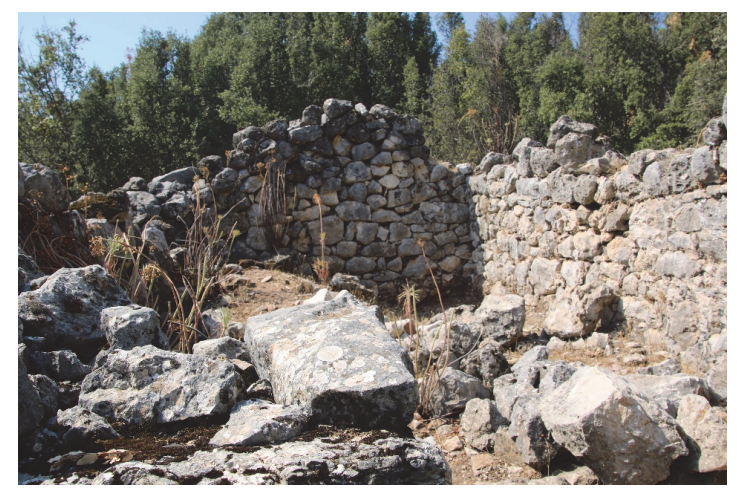

Fig. 4) Building remains at Asarcık/Aloanda

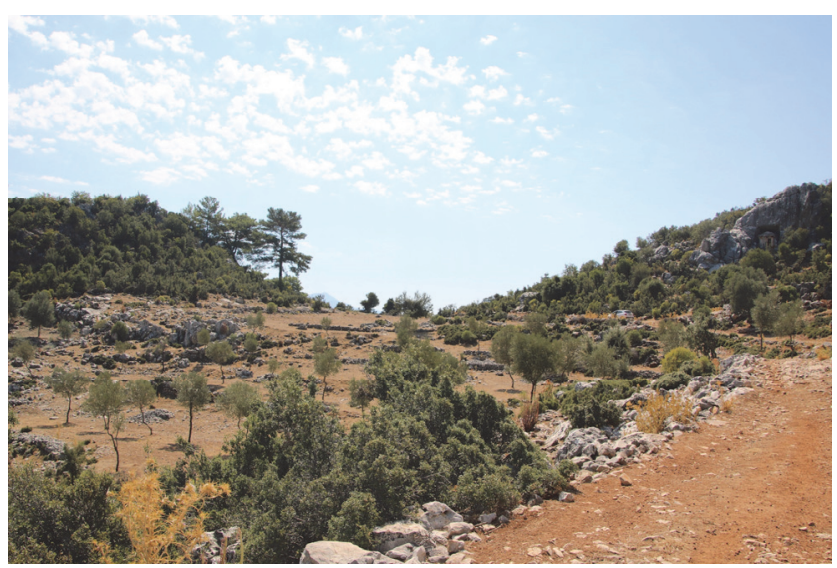

Fig. 5) The road pass between the hill of Aloanda remains (left) and the rock cut tomb (right) 
b) The route of Minare - Dip - Akbel on Babada $\breve{g}$ - Ocak Köyü - Keloğlu Boğazı - Fethiye

Hoskyn and Forbes had used another route from Pinara to Makri leading through today's Babadağ pass. ${ }^{15}$ Spratt and Forbes later twice used the same route from Makri (Telmessos / Fethiye) to Minare (Pinara) in 1842 when they began their journey in Lycia. Even though they do not give toponyms on this course, this can be understood from their description of the landscape. ${ }^{16}$ When they return to Makri, they took the coastal path from Sidyma passing by the harbours of Sancaklı and Faralya and reached Simbalu (Ölüdeniz), where they saw an ancient paved road, and then walked to Levissi (Karmylessos/Kayaköy), most probably through today's Hisarönü, finally arriving in Makri. ${ }^{17}$ The road from Hisarönü to Fethiye, passing by Kayaköy, and the route from Pinara to Hisarönü, leading through Babadağ pass (Akbel), seems to have been an optional course to reach Telmessos. Compared to the route through Esenköy and Gökben described above, the length of this route, ca. $32-33 \mathrm{~km}$, fits better with the distance given on the MP, and ancient tombs and Ottoman cisterns along it show that it was in continuous use. The road starts from Pinara, passing by the relief located ca. $300 \mathrm{~m}$ to the north of the theater (Fig. 7). Supported by newly repaired retaining walls, it passed by Gavurağlı and Gökkuyu (Fig. 8-Fig. 10), and reached Dip Mahallesi, where several rock cut tombs are visible (Fig. 11).

There was probably a connection from Aloanda to this road by the these rock cut tombs. Ca. $1 \mathrm{~km}$ to the west of these tombs, there is a single rock cut tomb (Fig. 12), which seems to have been collapsed. After climbing ca. $8 \mathrm{~km}$ from this point through several zigzags to reach Akbel, it is possible to see whole range of Akdağ and a great part of Xanthos Valley, just as described by Spratt and Forbes (see fn. 16). The road, up to ca. 3,5 $\mathrm{m}$ in width, can be traced in Akbel (Fig. 13-Fig. 14) . It then descends to the plain of upper Ölüdeniz, passing by three Ottoman cisterns (Fig. 15-Fig. 16), along the southern side of the stream bad, occasionally intersecting the modern road which leads to the Babadağ paragliding ticket office. Thereafter modern building in Ölüdeniz town has covered any traces. From Ölüdeniz there are two options to reach Telmessos: One can be observed starting from Ocak District and leading into Keloğlu Strait (Fig. 17-Fig. 20). The road with its retaining walls, ca. $2.4 \mathrm{~m}$. wide, can be easily followed along the strait. In some sections there are two old paths parallel to each other. At the end of the strait one branch descends to Taşyaka and disappears amongst the modern constructions in the plain; another, which is about $1 \mathrm{~km}$ longer, runs east towards Hisarönü and then Lebessos (Karmylessos/Kayaköy), and then turns north to Telmessos. There was already a connection from Telmessos to Lebessos (Karmylessos/Kayaköy), which was also an ancient site $^{18}$, and the remains of the paved road can still be seen today. Consequently, while

\footnotetext{
${ }^{15}$ Hoskyn 1842, 151 and see the map below p. 5 Fig. 6.

${ }^{16}$ Spratt - Forbes 1847, 5-6: "The commencement of our journey lay along the flat plain of Makri, from whence we ascended hills clothed with Vallonea (balanea) oak, a valuable tree in this country. From the summit of these hills we had a most magnificent view of the Massicytus mountains, forming a long range of many summits, belted at mid-height by dark forests of pine, and towards their bases by thick green woods of oak. We descended into the valley of Xanthus, which in this part is broken up by many flat-topped yellow hills, with here and there a dark red cone of rock rising among them." Their second excursion is mentioned on p. 24.

${ }^{17}$ Spratt - Forbes 1847, 19-24.

${ }^{18}$ See Tietz 2003, 334-337; Hellenkemper - Hild 2004, II, 681-683, s.v. Lebissos.
} 
this mountainous eastern route passing over Babadağ seems more convenient, no certain option for the road recorded in the MP is available.

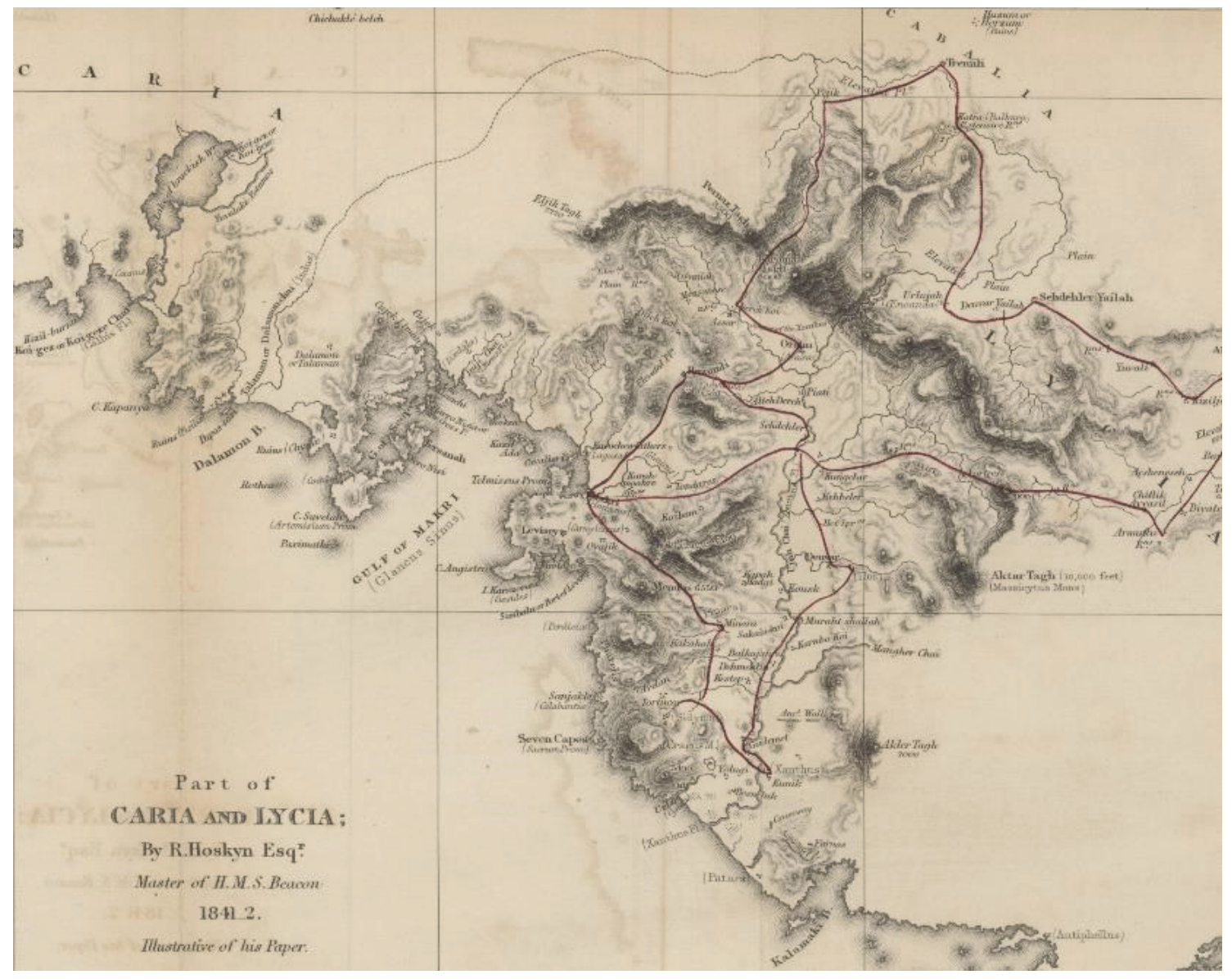

Fig. 6) Hoskyn's Map, 1842 (ref. in dn. 15 above)

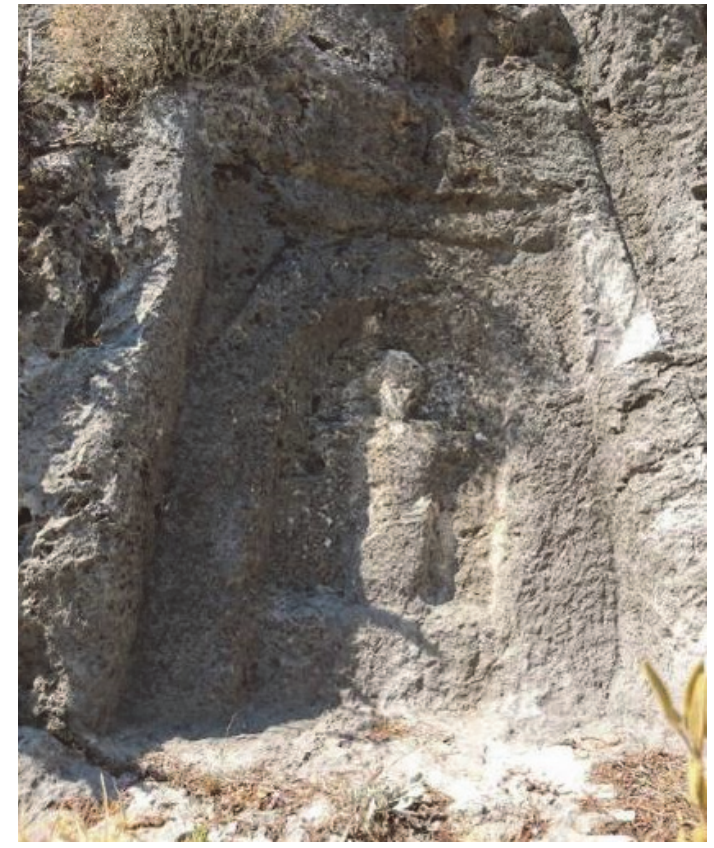

Fig. 7) Pinara - Telmessos. The relief on the road

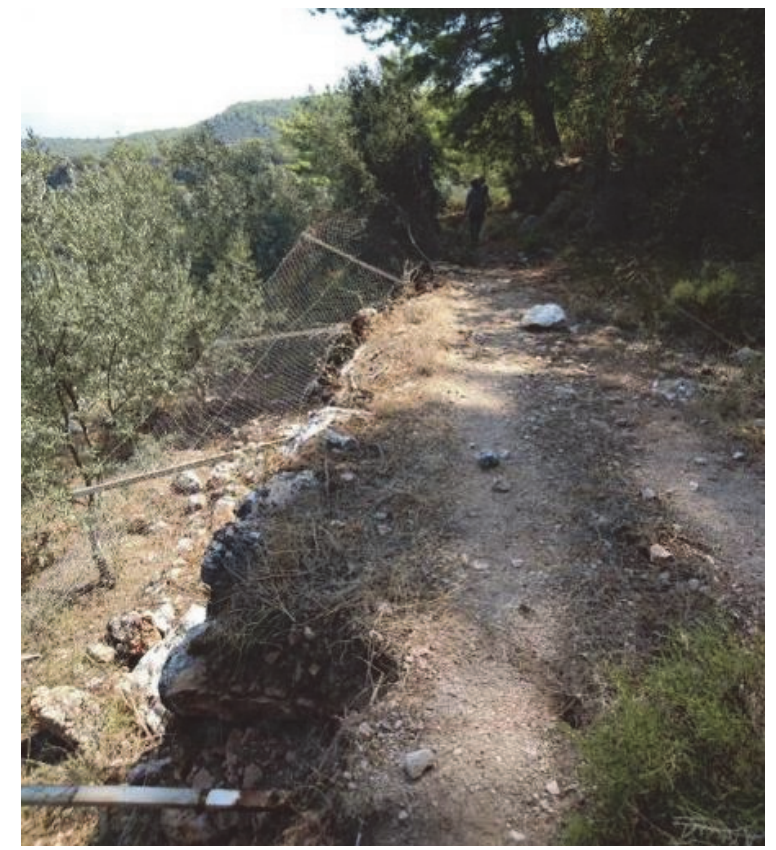

Fig. 8) Pinara - Telmessos. The road with retaining walls 


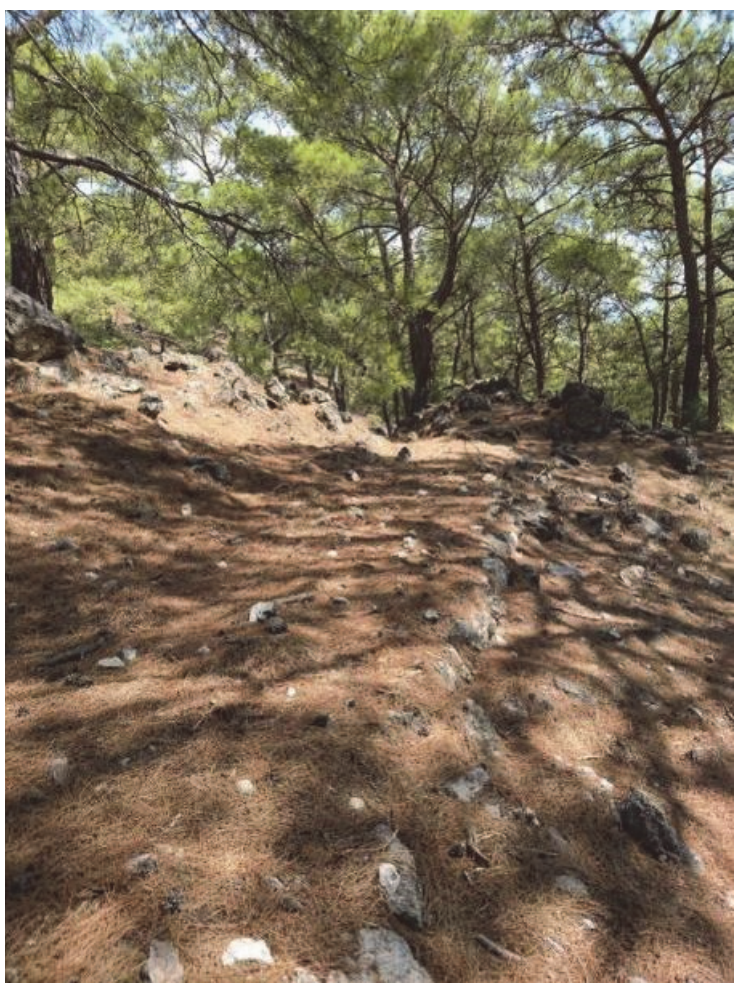

Fig. 9) Pinara - Telmessos. The ancient road

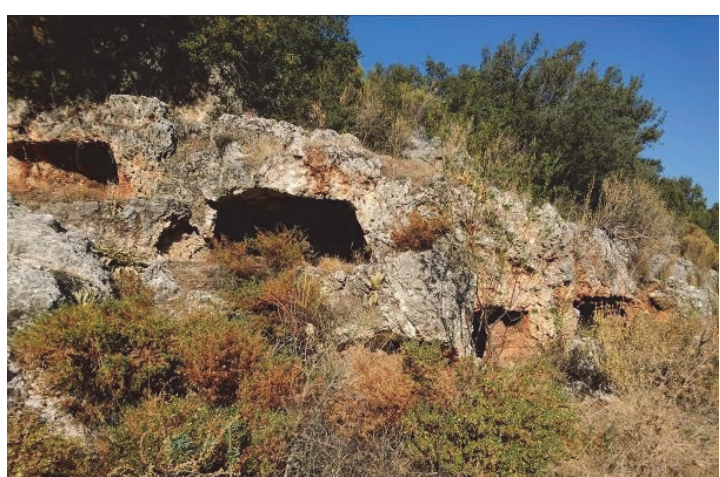

Fig. 11) Pinara - Telmessos. The rock cut tombs to the south of Dip district

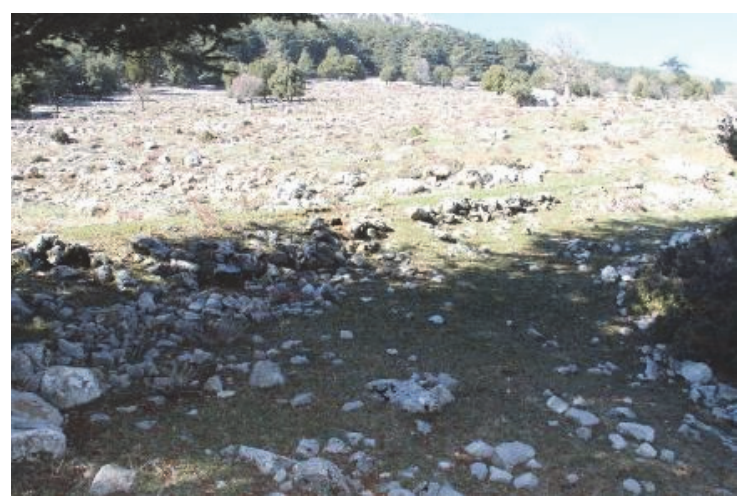

Fig. 13) Pinara - Telmessos.

Retaining walls of the road in Akbel

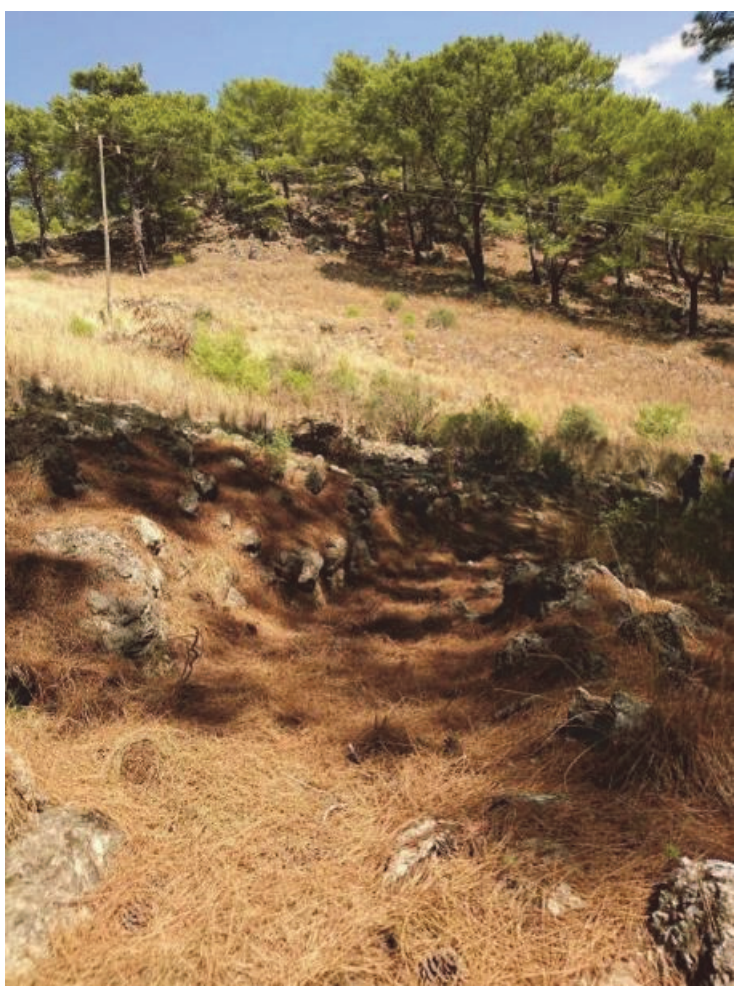

Fig. 10) Pinara - Telmessos. The ancient road

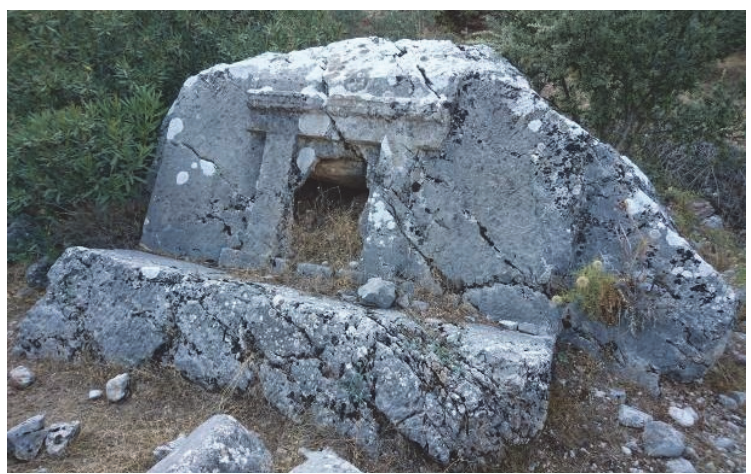

Fig. 12) Pinara - Telmessos. The rock cut tomb to the north of Dip district

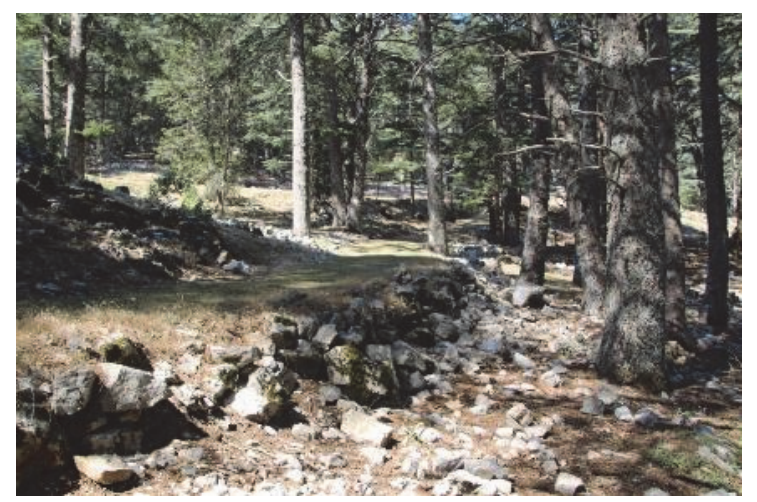

Fig. 14) Pinara - Telmessos.

Retaining walls of the road in Akbel 


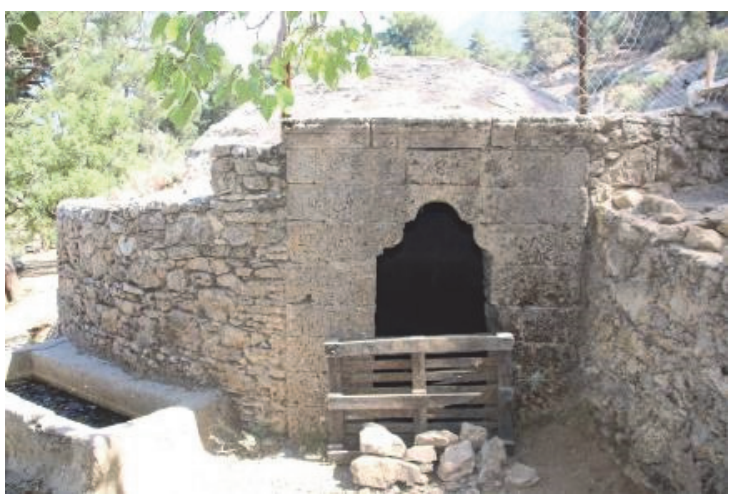

Fig. 15) Pinara - Telmessos. Ottoman cistern

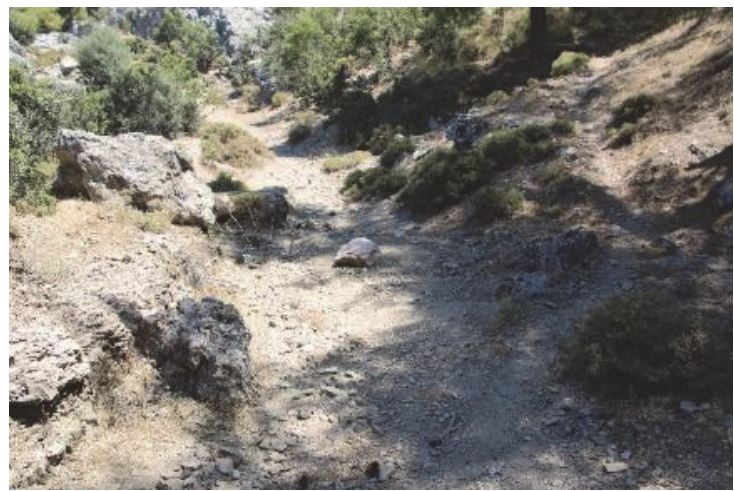

Fig. 17) Pinara - Telmessos.

The road from Ocak District into Keloğlu strait

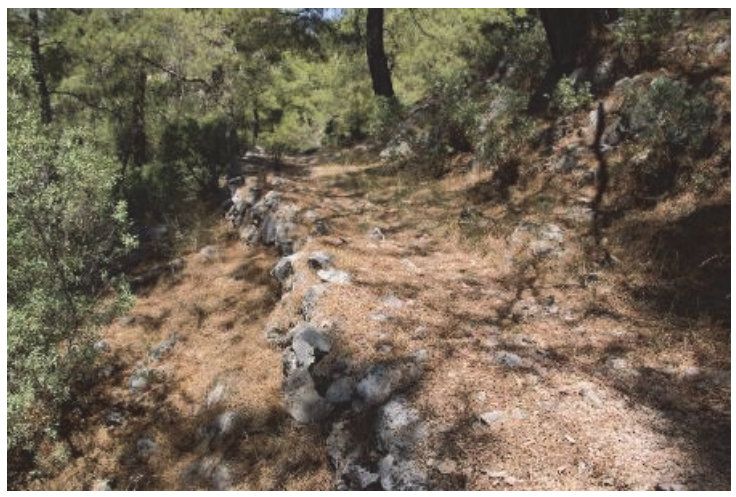

Fig. 19) Pinara - Telmessos.

The road from Ocak District into Keloğlu strait

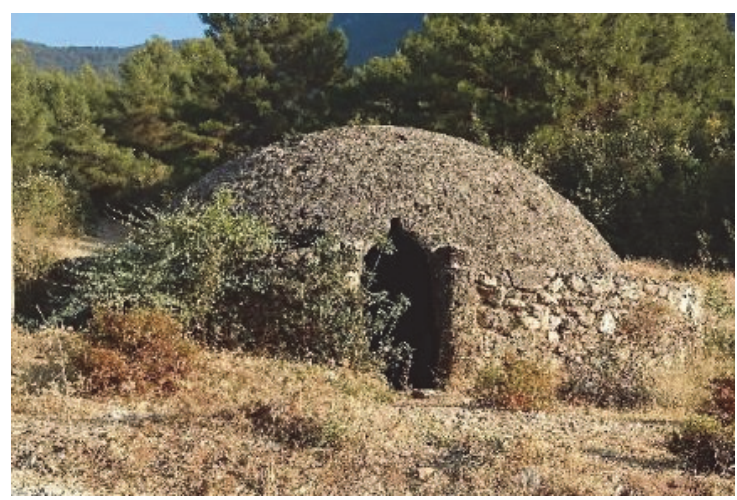

Fig. 16) Pinara - Telmessos. Ottoman cistern in Ovacık

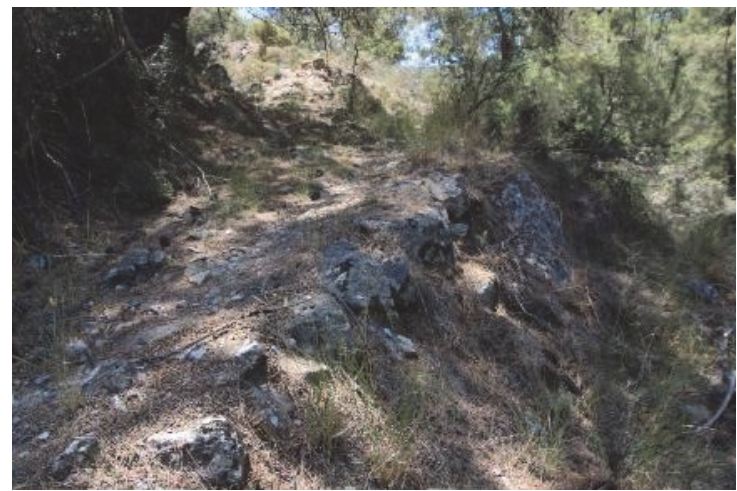

Fig. 18) Pinara - Telmessos.

The road from Ocak District into Keloğlu strait

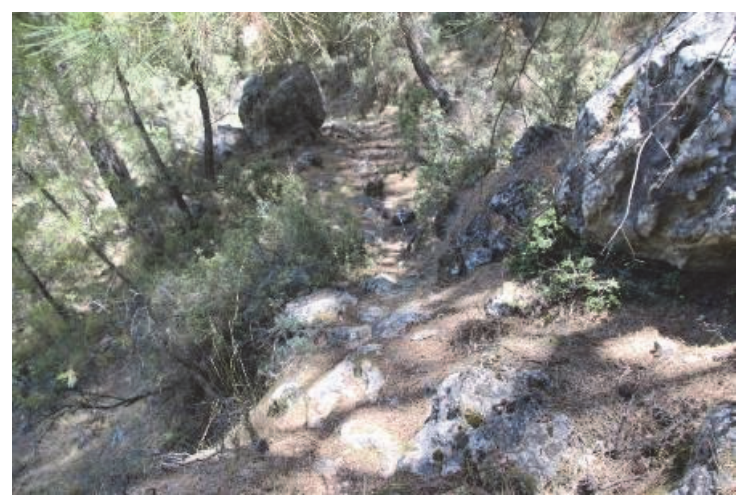

Fig. 20) Pinara - Telmessos.

The road from Ocak District into Keloğlu strait

\section{From Tlos to Telmessos (R10), 188 stades, ca. $34,8 \mathrm{~km}$}

The direct road from Tlos to Telmessos is one of the longest roads presented in the MP. It is understood that the territories of Telmessos and Tlos were adjacent near the Xanthos (Eşen) River, which must have been crossed somewhere near today's Seydikemer. The well-known bridge in Atlidere (Fig. 37-Fig. 38), ca. $5 \mathrm{~km}$ to the north of Seydikemer, would have been a good option for crossing, but the existence of a direct road between Kadyanda and Tlos indicates that this bridge probably belonged to Kadyanda. Further, a road over this bridge would have been longer than $35 \mathrm{~km}$. So another bridge for the road between Tlos and Telmessos should be looked for further south. One of the options might be the point in Seydikemer, where a relatively old bridge on the older road to Fethiye is still in use (Fig. 21-Fig. 22). If there was a bridge in antiquity on the same spot, the distance of the route from Tlos through Kincilar and Seydikemer is only slightly 
longer than the distance in the MP (ca. $37 \mathrm{~km}$ ). However, a better option is in Alllkavak, where we have found a footing of an ancient bridge (Fig. 27-Fig. 28). This ancient bridge could have served the roads from Tlos to Pinara and to Telmessos, which followed the same route to a point right after the bridge. In the old Turkish cemetery called Gültepe east of this bridge and on the line of the road leading to it, there are remains of columns, some which might be milestones (we could not see the parts buried in the ground), column bases and other architectural fragments (Fig. 23-Fig. 24). On the road between the cemetery and the bridge there is also an old mill locally called Gavurun Değirmeni ("the mill of the infidel") referring to its use in pre-Turkish period (Fig. 25-Fig. 26). After Allıkavak, the road to Pinara continues towards Alaçat and Minare, while the one to Telmessos takes a path through Çaltıözü, Bozyer and Esenköy. To the south of Çaltıözü a relief of soldier facing the ancient path is carved on the rocks (Fig. 29). The trace of the ancient path can be followed near Damlaca and Aktaş to the east of Bozyer (Fig. 30). Based upon the reports of an ancient road, which lay east of Hizırlık Hill, Buschman thought that the road after Esenköy did not take a route through the plain but continued through the slopes at ca. $300 \mathrm{~m}$ above sea level passing through Hizırlık Hill, located to the south of the Fethiye Plain, and finally reaching to Fethiye. ${ }^{19}$

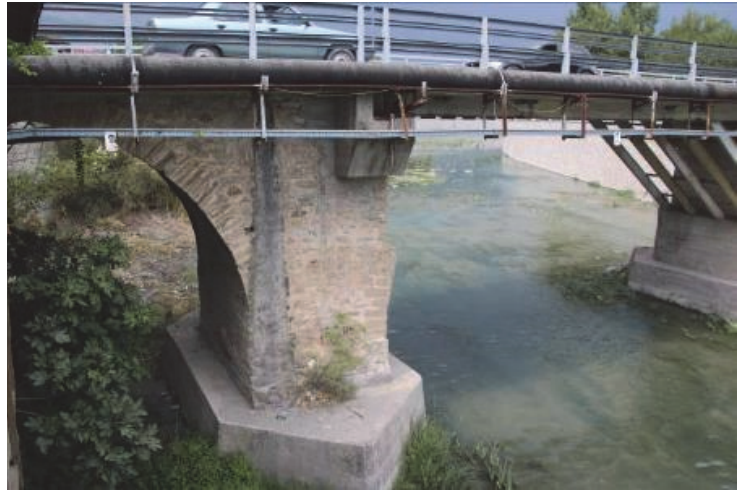

Fig. 21) The bridge of Seydikemer

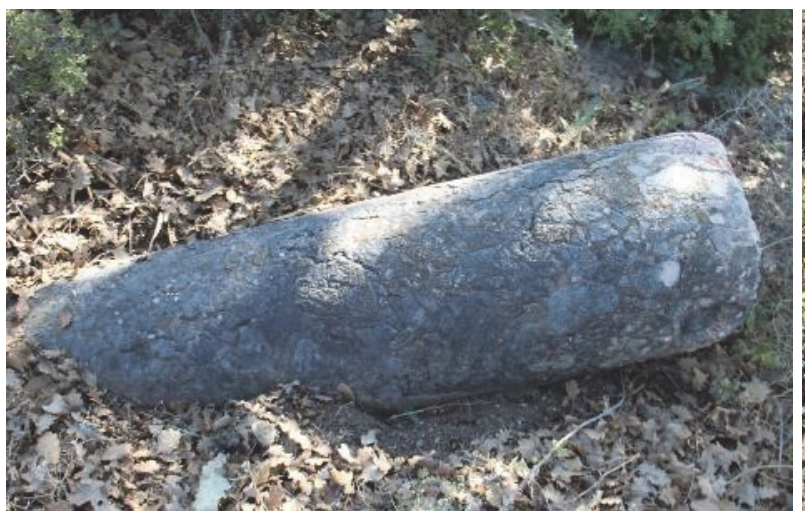

Fig. 23) Tlos - Pinara/Telmessos.

A column in the cemetery of Gültepe

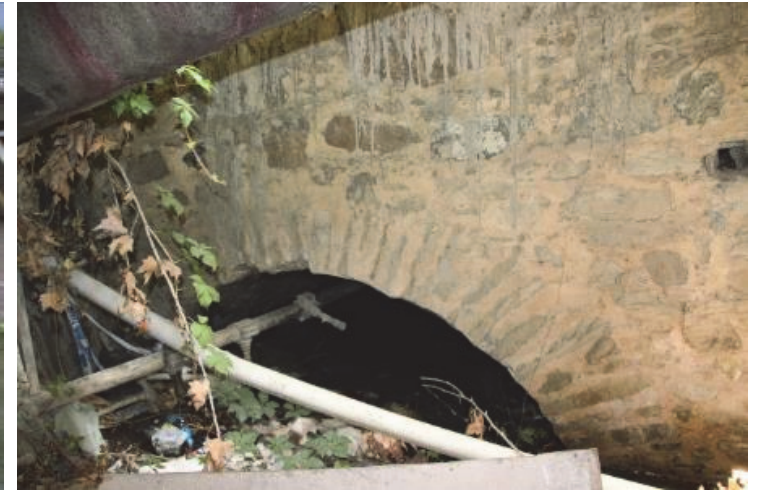

Fig. 22) The bridge of Seydikemer

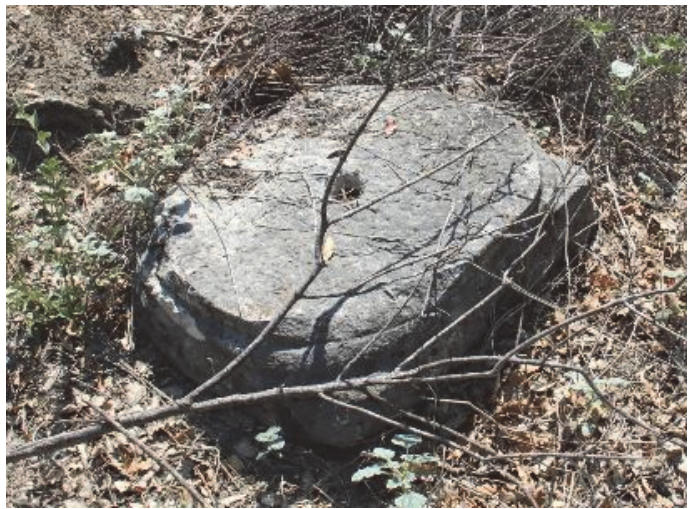

Fig. 24) Tlos - Pinara/Telmessos.

Column base in the cemetery of Gültepe

${ }^{19}$ Buschmann 1993, 430. 


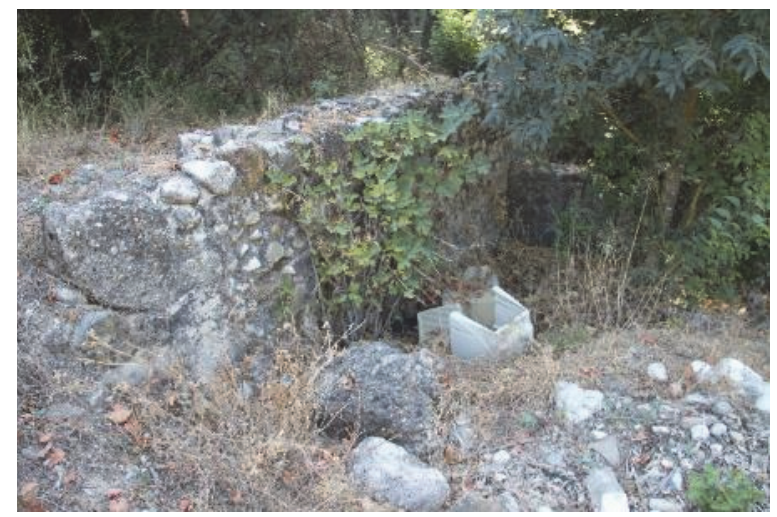

Fig. 25) Gavurun Değirmeni ("The mill of infidel”)

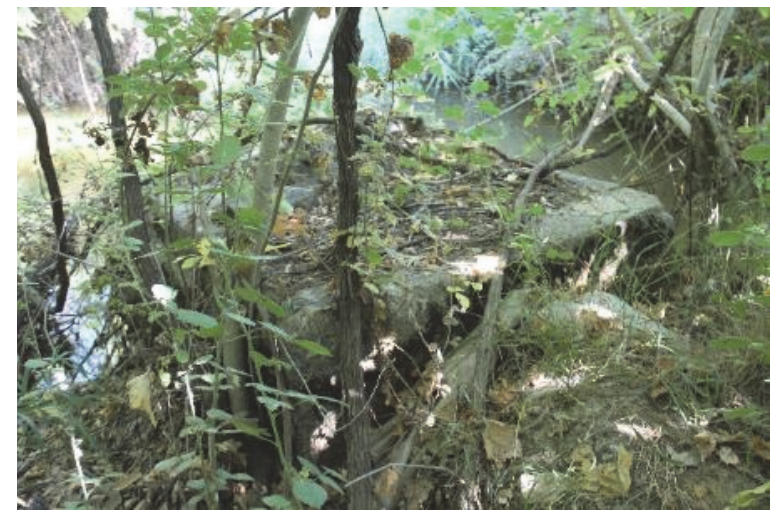

Fig. 27) Allkavak. Remnant of a bridge pier

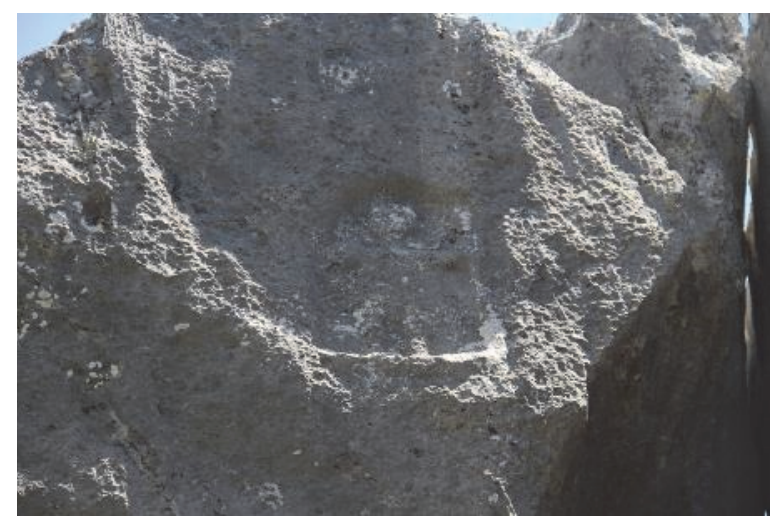

Fig. 29) Tlos - Telmessos.

A relief of soldier to the south of Çaltı̈̈zü

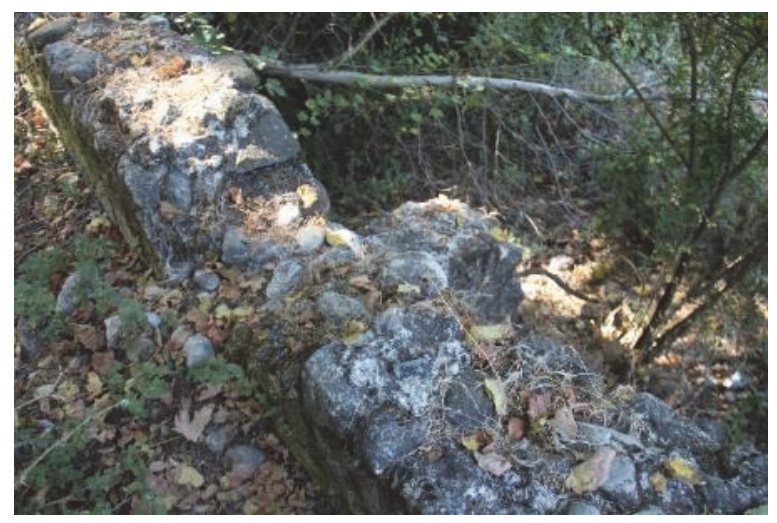

Fig. 26) Gavurun Değirmeni ("The mill of infidel”)

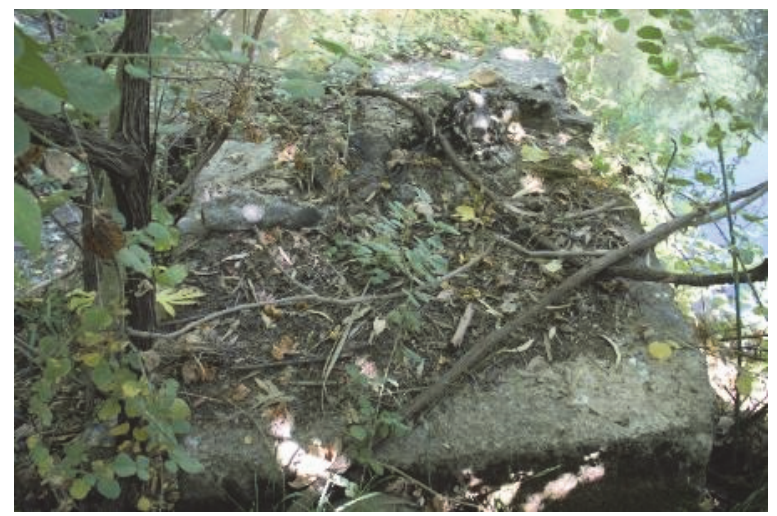

Fig. 28) Allikavak Mevki. Remnant of a bridge pier

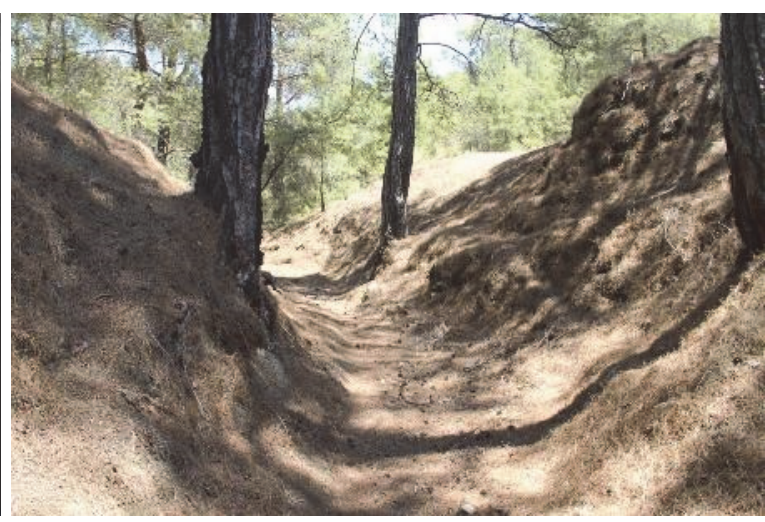

Fig. 30) Tlos - Telmessos.

The old road near Damlaca

\section{From Telmessos to Kalynda (R11), 184 stades, ca. 34 km}

Unfortunately, due to the restrictions in the permission given by the ministry for the county of Dalaman, we could not complete a full field survey within this area, but certain aspects can still be discussed. Almost everyone who has written about the matter has suggested that the ruins of Kalynda are located in Kozpınar - Şerefler. ${ }^{20}$ This localization has recently been re-considered by Sencer Şahin, who believed that the ruins in İnlice Asarı, which was believed to have been Daidala,

${ }^{20}$ DGRG s.v. Calynda; Bürchner 1919, 1771-1772; Jameson 1974, 214; Bean 1976a, 434; Zgusta 1984, 215, §414-2; Kaletsch 1999, 214; Tietz 2003, 201-230; Hellenkemper - Hild 2004, 594-595; TAVO B V 15; BATL 65;. For a different view see. Tietz 2003, 201. L. Robert also thought that the town's location was unclear, Robert 1937, 493. 
should in fact be identified with Kalynda. ${ }^{21}$ Şahin's proposal for İnlice Asarı is based upon two main basic arguments. The first is that the localisation of Kalynda at Şerefler-Kozpınar contradicts the MP, since i.e. a route from Telmessos to Hippoukome through Şerefler would have lenghtened the journey by additional ca. $55 \mathrm{~km}$. So, it is more plausible to locate Kalynda at İnlice Asarı, which is on a more direct line from Hippoukome to Telmessos. The second is that the frontier between Kaunos/Karia and Lykia was not Indos River, but the mountains between Şerefler and İnlice, which is situated within this range. This depends on the accounts of Herodotos and Quintus Smyrnaeus ${ }^{22}$, which he interpreted as excluding lands around Şerefler from Lycian territory. So in order to pass these mountains the road would have had to run through the ruins of İnlice ruins, which belonged to an important ancient settlement and could not have been omitted by the MP. To support his position, Şahin used Strabo's account ${ }^{23}$ and the Neronian customs inscription from Andriake ${ }^{24}$. Since the accounts of Herodotos and Ptolemaios indicate that Kalynda was located on the seashore ${ }^{25}$, he finds Inlice Asarı a better candidate since it was close to the sea (ca. 1,5 km). To deal with the problem that, the lengths given in the MP for the roads between Telmessos and Kalynda (ca. $33 \mathrm{~km}$ ) and between Kalynda and Kaunos (ca. $20 \mathrm{~km}$ ) do not fit, he proposed that these distances were substituted for each other on the monument by mistake. B. Karabulut, who

${ }^{21}$ Şahin - Adak 2007, 152-157; Şahin 2014, 176-183.

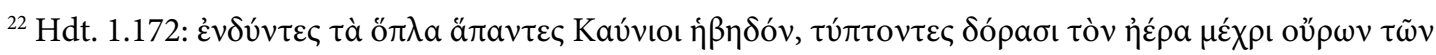

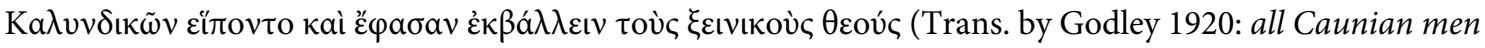
of full age put on their armor and went together as far as the boundaries of Calynda, striking the air with their

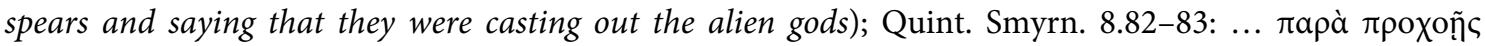

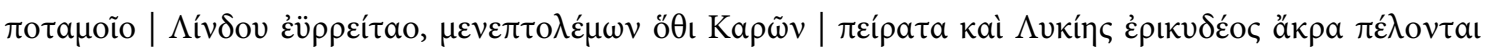
(Trans. by Way 1913: where the lovely streams of Lindus meet the sea, beside the marches of battle-biding Carians, and the heights of Lycia the renowned).

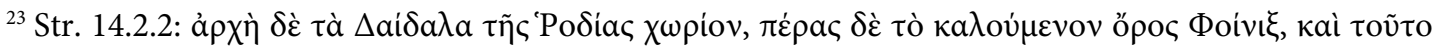

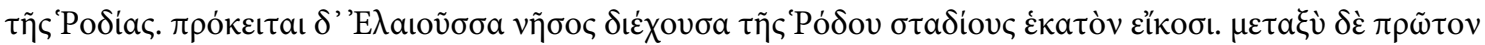

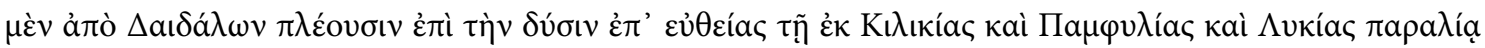

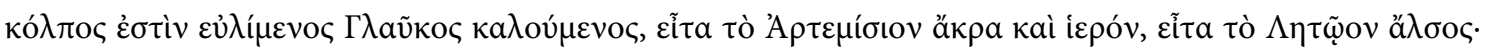

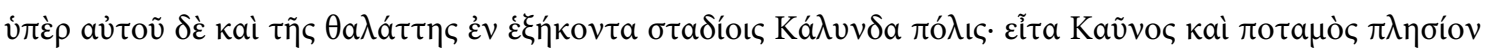

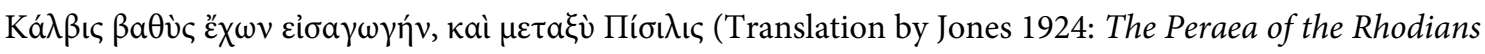
begins with Daedala, a place in the Rhodian territory, but ends with Mt. Phoenix, as it is called, which is also in the Rhodian territory. Off the Peraea lies the island Elaeussa, distant one hundred and twenty stadia from Rhodes. Between the two, as one sails towards the west in a straight line with the coast of Cilicia and Pamphylia and Lycia, one comes to a gulf called Glaucus, which has good harbors; then to the Artemisium, a promontory and temple; then to the sacred precinct of Leto, above which, and above the sea, at a distance of sixty stadia, lies Calynda, a city; then to Caunus and to the Calbis, a river near Caunus, which is deep and affords passage for merchant vessels; and between the two lies Pisilis.).

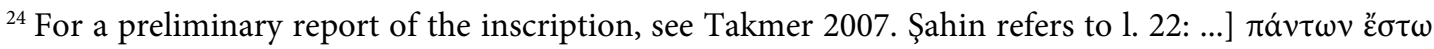

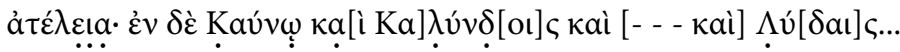

${ }^{25}$ Hdt. 8.87.2 (Artemisia I of Caria rams a Kalyndan ship during the battle of Salamis in ca. 480 BC):

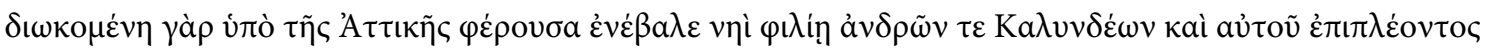

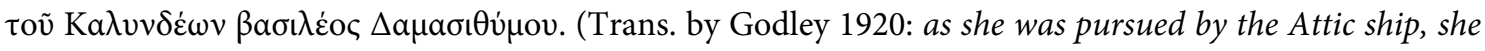
charged and rammed an allied ship, with a Calyndan crew and Damasithymus himself, king of the Calyndans,

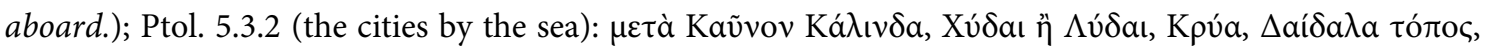

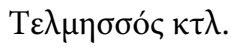


carefully investigated Şahin's arguments and rightly objected to his approach, reported that this proposition can not be justified, and that Kalynda should be located at Kozpınar-Şerefler as was widely accepted formerly. ${ }^{26}$

We should not take the MP as a journey planning tool. The list on the MP is an official inventory of the roads, which were built or renovated and measured in the reign of Claudius. So we cannot think that one had to go through Kalynda to reach Hippoukome from Telmessos, and the location of Kalynda is entirely irrelevant to such a discussion. Even in this case, one does not need to stop at Büyükasar Tepesi (= İnlice Asarı) to go to Lyrnai or Hippoukome from Telmessos, since such a route would have turned north even before going down to the İnlice River. The account of Herodotos (fn. 22) does not provide certain evidence that the mountains were the borderline

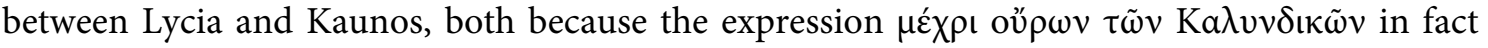
refers to the "frontiers" not the "mountains" at the edge of Kaunian territory, ${ }^{27}$ and in any case the account is much earlier than the MP. The statement of Quintus Smyrnaeus (fn. 22), who wrote in $4^{\text {th }} \mathrm{c}$. $\mathrm{AD}$, indicates only that the mountains east of the Indos were in the Lycian territory, but not necessarily that the area between the Indos and the "Lycian heights" belonged to Kaunos. So, Kalynda, can still be identified as the most westerly station in the MP.

We can even consider the ruins in İnlice Asarı to have been a frontier fortress, at least during Early Empire, either at the western edge of Telmessan territory or, better, at the eastern edge of Kalyndan territory, since the settlement in İnlice Asarı was a point that looked northeast, south and east, and a position where the road from Telmessos leads to the valley of İnlice River, which might have formed a natural border as well. This might well be the reason why the MP did not mention a settlement in the area. It is usually accepted that the ruins in İnlice Asarı and in Velidada on the coast belonged to Daidala, which was believed to have remained in Rhodian Peraia until the Diocletanic provincial re-organisation. ${ }^{28}$ One point concerning the MP is important in this discussion. The territories both of Lycian poleis and of independent states such as Termessos were indicated on the monument, when a road ran through them. ${ }^{29}$ If there was a Rhodian territory on the road from Telmessos to Kalynda, it would probably have been indicated with a phrase such as

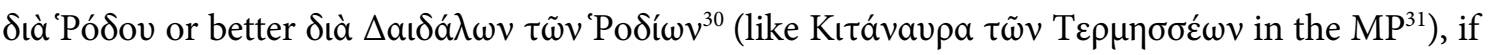
indeed İnlice Asarı was the site of Daidala and a part of Rhodian territory in the early imperial period. In fact, it is highly probable that there was no Rhodian territory on the road from Telmessos to Kalynda. This implies either that Daidala was not located at İnlice Asarı, but somewhere else perhaps to the south-west on Kapudağ Peninsula, or that Daidala, if it was at İnlice, became incorporated in the territory of Kalynda or Telmessos under the administrative control of Roman

${ }^{26}$ Karabulut 2019, 78-81.

${ }^{27}$ See also Tietz 2003, 86-87 and 112, preferring the meaning of "frontiers", considering that otherwise Kalynda seems have had no lands in Dalaman Plain, while in fact there should have been Kalyndan areas in the plain.

${ }^{28}$ For a lenghty account of the subject see Tietz 2003, 243-247.

${ }^{29}$ This subject has been discussed in detail in Onur 2016.

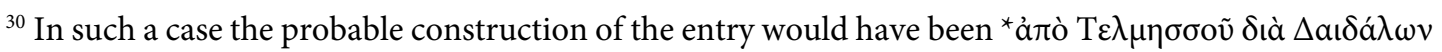

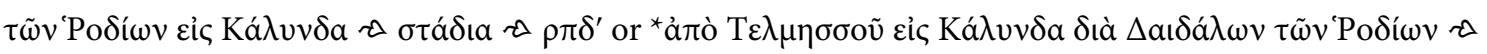
$\sigma \tau \alpha ́ \delta ı \curvearrowright \curvearrowright \rho \pi \delta^{\prime}$.

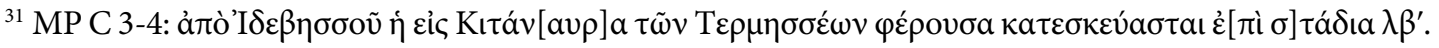


governor before or during the organization of provincia Lyciae in $43 \mathrm{AD}$. Cassius Dio recorded that Rhodes was deprived of its liberty and attached to province of Asia by Claudius in $44 \mathrm{AD} .{ }^{32}$ In such a case Daidala might have well remained in the Lycian territory.

Strabon's account (fn. 23) is actually a better indicator of the location of Kalynda. The promontary of Artemision, accepted as today's Kurtoğlu Burnu, lay west of Glaukos Kolpos, the golf of Fethiye. Then came the grove of Leto near the sea, which was most probably located at the southeastern end of Kargın Gölü ${ }^{33}$, ca. $11 \mathrm{~km}$ to the south of Şerefler/Kozpınar. Strabon reckoned 60 stadia (ca. 11 $\mathrm{km}$ ) to Kalynda from the grove of Leto. Şahin considers that this distance of 60 stadia was between İnlice Asarı (or a harbour attached to the settlement at İnlice Asarı) and Kurtoğlu Burnu, but the real distance between these two locations is at least $20 \mathrm{~km}$ as the crow flies. It is not a large problem to locate Kalynda as a destination for maritime trade around Şerefler/Kozpınarı, and there is no need to assume a river connection, as there was a comparable relation between Myra and the port Andriake. We should be aware that the coastline of the Dalaman Plain in antiquity was probably near modern Dalaman. Geological surveys show that Dalaman River changed its bed from the Dalyan Plain to Dalaman Plain in ca. 500 BC, and this suggests that Kalynda's main harbour was probably in the eastern inner section of the Dalaman Plain, which had once been a bay with several islands. ${ }^{34}$ Additionally, there is no reason to suggest that the measurements on the MP between Telmessos, Kalynda and Kaunos might have been switched by mistake. This would have been a very unexpected error in a magnificent monument, whose text would have been examined at every step of its composition and construction.

No road is indicated from Kalynda to the southern settlements such as Lydai, which was already a Lycian polis in Claudian period ${ }^{35}$, most probably because there was no land route for mass transport to Kapudağ Peninsula and to the settlements on it. There is also no access for vehicles today. The distance from Kalynda to Kaunos is ca. $20 \mathrm{~km}$ in the MP, which falls short to reach Kaunos. If the road led through today's Ortaca, it ended right before reaching Okçular, ca. $5 \mathrm{~km}$ to the east of Kaunos. If it lead through Mergenli and Gökbel, it would have ended around Sülüngür Lake, which is closer to Kaunos. More detailed geological surveys are needed in the Dalaman Plain to get an exact answer as to which road was measured in the MP. Both of these suggestions make sense, since in antiquity Dalyan, the harbour of Kaunos, was surrounded by sea, and there was no land route to Kaunos from these points. But the second option seems more plausible in terms of the topography of the area, as it was shorter route and ended sensibly in a bay northeast of Sülüngür Lake, which was apparently a sheltered good harbour in antiquity, near the ancient Pas(s)anda ${ }^{36}$, southeast of the Kaunian golf. The milestone found in Osmaniye ${ }^{37}$ nearby ancient Pisilis probably did not belong to a road between Kaunos and Kalynda, since its remains too far south to establish a route of ca. 20 $\mathrm{km}$.

\footnotetext{
${ }^{32}$ Dio 60.24.4; see also Tietz 2003, 246-247 and Köktürk - Milner 2003, 136.

${ }^{33}$ See Tietz 2003, 177-178.

${ }^{34}$ Pons - Edelman 1963, 32-34, 37 and 41; Doğu 1988, 323-324; Çeker 2016, 31-32; see also Tietz 2003,

${ }^{35}$ For a full account on Lycian entity of Lydai see Tietz 2003, 142-154.

${ }^{36}$ Bean 1976b, 679; See also https://topostext.org/place/368287UPas (accessed on 17/08/2019).

${ }^{37}$ Marek 2006, 336 no. 145; French 2014, 230 no. 124.
} 204-206. 


\section{From Kadyanda to Telmessos (R17), 104 stades, ca. 19,3 km.}

There are two possible routes for this road. The first is the the modern road, while the second is the one through Eldirek. ${ }^{38}$ There are remains of a paved old road (probaby not ancient) in the place called Paşadöğüşlü near Çatalçeşme on the modern road (Fig. 31-Fig. 32). This old road, the width of which reachs $4,10 \mathrm{~m}$ in some sections, can be followed with its pavements and retaining walls south for around $300 \mathrm{~m}$. However, the length of this route is ca. $21 \mathrm{~km}$. The second route through Eldirek fits the distance given in the MP.

There are several ancient remains found around Eldirek. There is a rock cut tomb to the north, on the southern slope of a hill called Asar. Traces of ancient occupation on the Asar Hill include flattened rock surfaces and numerous ancient ceramics. There are remains of retaining walls belonging to an old road 200/300 m northeast of Asar Hill. Many more ceramic fragments were observed along the path and especially in Zeytinlik. The remains of a building probably belonging to a farmstead was recorded in Çubuk in the direction of Üzümlü from Eldirek (Fig. 33). A large ancient quarry, and remains of another $6 \times 6 \mathrm{~m}$ building (probably a tower) were observed in Tekirlik on the same route to Kadyanda (Fig. 34).

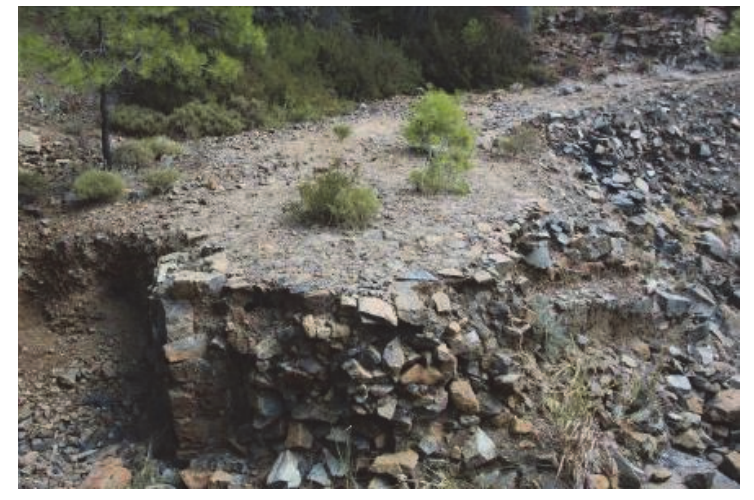

Fig. 31) Paşadöğüş̧ü. Road pavement

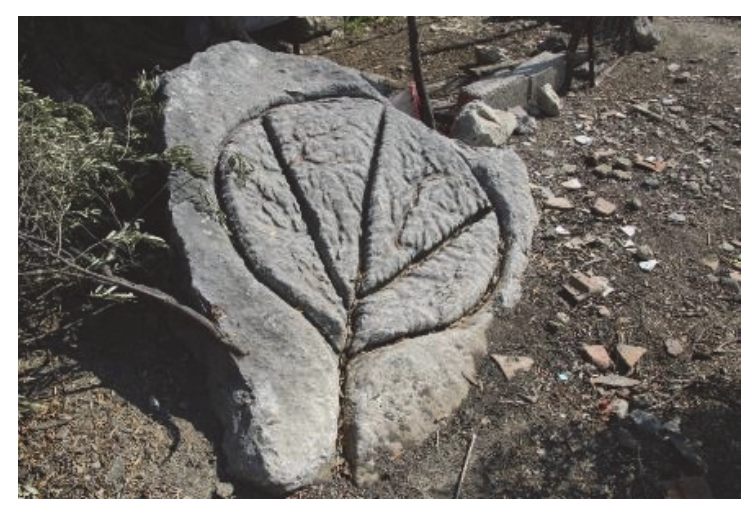

Fig. 33) Eldirek. Press-stone

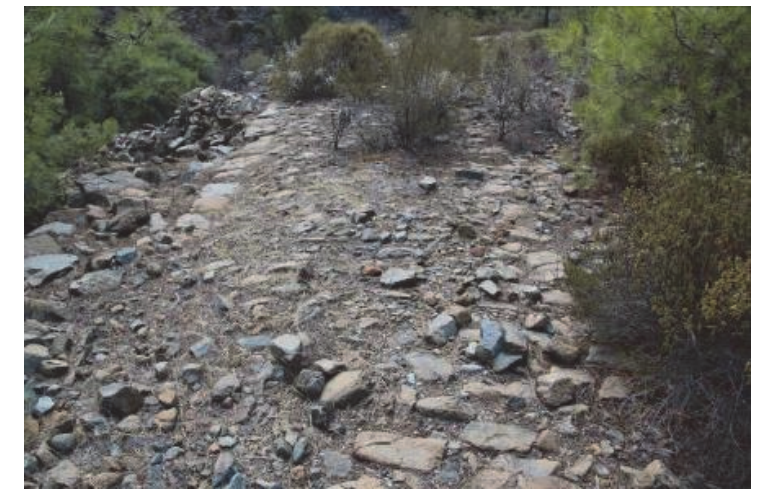

Fig. 32) Paşadöğüşlü. Road pavement

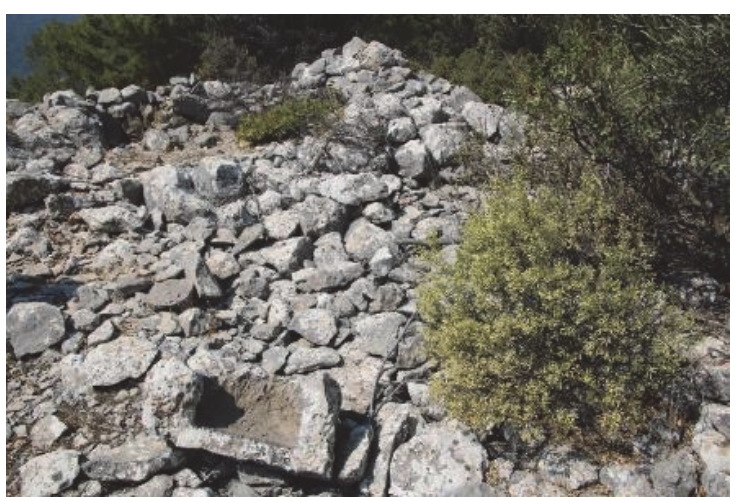

Fig. 34) To the north of Eldirek. Ruins at Tekirlik Mevki

\section{From Kadyanda to Araxa (R18), 108 stades, ca. 20 km.}

There is only one option for this road, that is modern road, at least until Ortaköy. No trace of the ancient road remains today. The road starting from the west side of Kadyanda should have lead down to modern road, probably to the point, where an Ottoman cistern still stands (Fig. 35). The ancient route near Ortaköy probably took a southern course to reach Araxa after $20 \mathrm{~km}$, crossing

\footnotetext{
${ }^{38}$ See also Tietz 2003, 338 fn. 241 and Şahin 2014, 194.
} 
the Xanthus River at the Atlidere Bridge. Today's road, which passes the modern bridge, is too short for the distance in the MP, and a northern route is less probable because of the large bed of Akçay. The northern part of the route between Tlos and Araxa already included a road from Atlidere to Araxa.

There is a rock-cut tomb with a Lycian inscription in the hamlet of Sazak (Fig. 36), already reported by early travellers (see below p. 17), on the road from Kadyanda to Araxa, two kilometers before it reaches Ortaköy. It is difficult to ascertain to which of two cities the tomb belonged. It is closer to Araxa, but the location is a pass just before the Xanthus Plain. The road from Kadyanda to Tlos should run this way and this indicates that Kadyanda's territory extended at least until the Atlidere Bridge. So, the tomb remained most probably in Kadyandan territory.

\section{From Kadyanda to Tlos (R19), 160 stades, ca. $29,6 \mathrm{~km}$.}

This road followed the same route as R18 to Araxa at least until near Ortaköy. There might be another way of reaching Seydikemer through Kayacık, but such a road would be problematic since it would have entered Telmessan territory, and a bridge connecting Tlos with both Kadyanda and Telmessos would have been required near or in Seydikemer. Thus, the road seems to have reached Atlidere bridge (Fig. 37-Fig. 38), passing the slopes south of Ortaköy, without getting into Araxan lands. Two roads entered the territory of Tlos after or at the Atlidere bridge. The course from here to Tlos should have taken the old road to Kincilar, passing Tezli Dere, east of Girmeler and Güneşli. There is no remaining trace of ancient construction on this old road.

\section{From Araxa to Tlos (R20), 120 stades, ca. 22,2 km}

The course of the road leaving Araxa followed the eastern banks of Xanthus River, passing Sahil Ceylan to the south, and reaches Kincilar. The route is the same as the road from Kadyanda and is quite straight, perfectly matching the distance given in the MP.

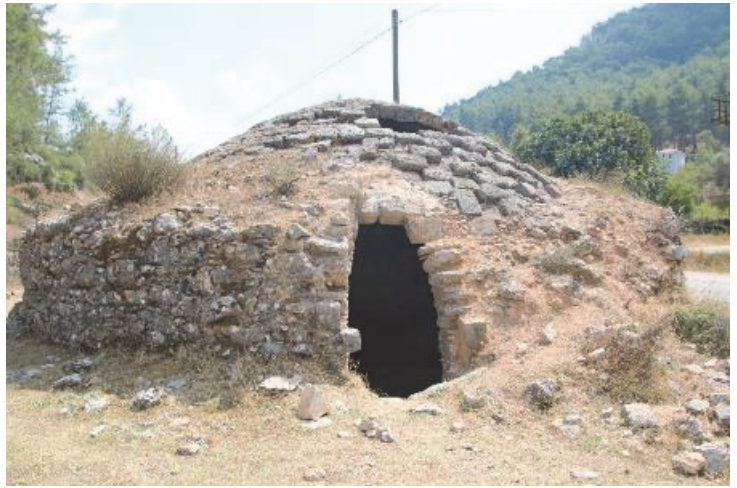

Fig. 35) Kadyanda - Araxa. Ottoman cistern in Üzümlü

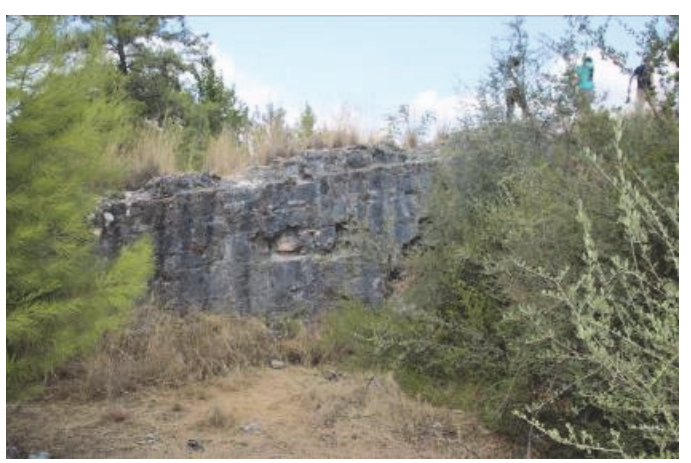

Fig. 37) Atlıdere Bridge

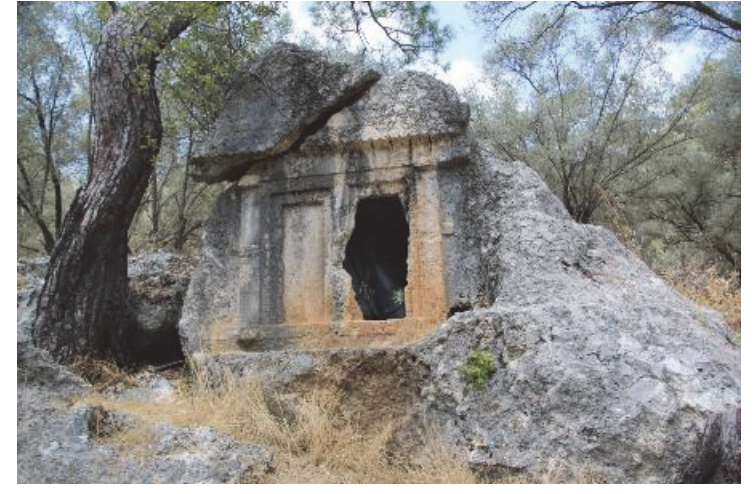

Fig. 36) Kadyanda - Araxa. Rockcut tomb in Sazak

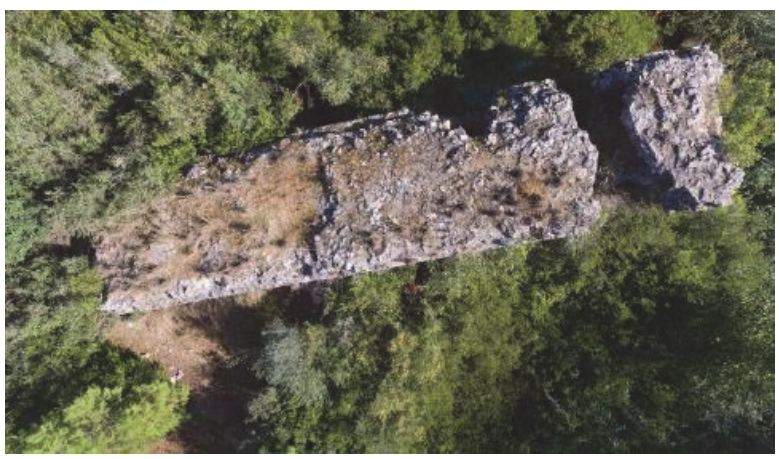

Fig. 38) Atlıdere Bridge 


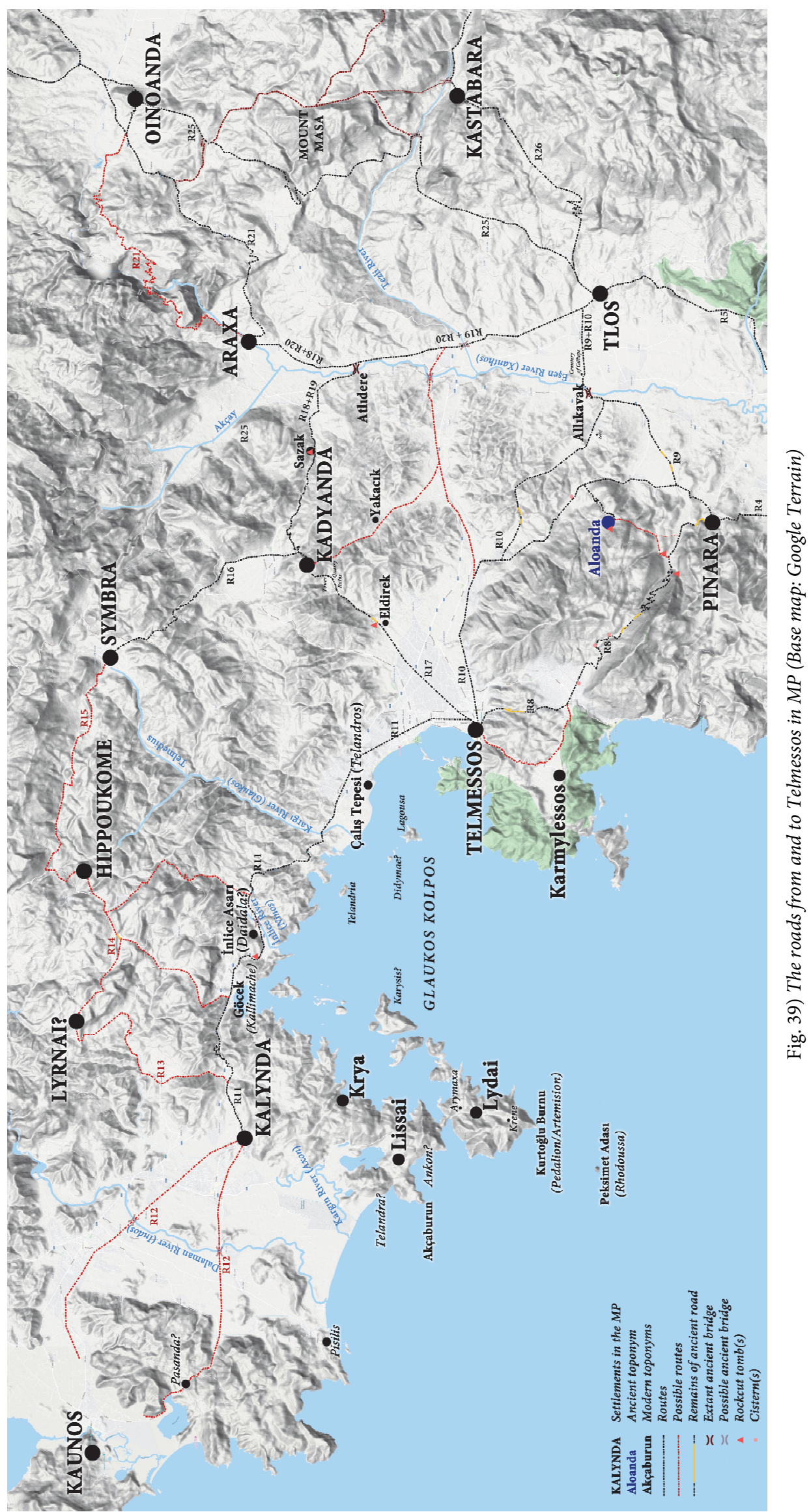




\section{The New Lycian Inscriptions (R. TEKOĞLU)}

The following two inscriptions in the Lycian language were found at Aloanda and Kadyanda during the survey on the ancient road systems in Lycia mentioned above (see. p. 1).

\section{No. 1) Asarcık / Aloanda}

Aloanda is an ancient site to the north of Pinara. There are several inscriptions from the settlement. This inscription was found near a Greek inscription from Hellenistic period, which records a funerary foundation of an annual feast in honour of a certain Pokomas. The following reading of the inscription is based upon the squeeze and photographs taken by Fatih Onur and from an inspection made by me in a visit with the survey team. It is on a rectangular limestone block. The left side and the top of the inscription, in its standing position, are broken and lost. In the preserved lines, the word dividers seem to have been regularly employed (Fig. 40 and Fig. 42). In the following reading, some lines and signs were corrected after checking, slightly changing the text presented at the Munich Workshop ${ }^{39}$.

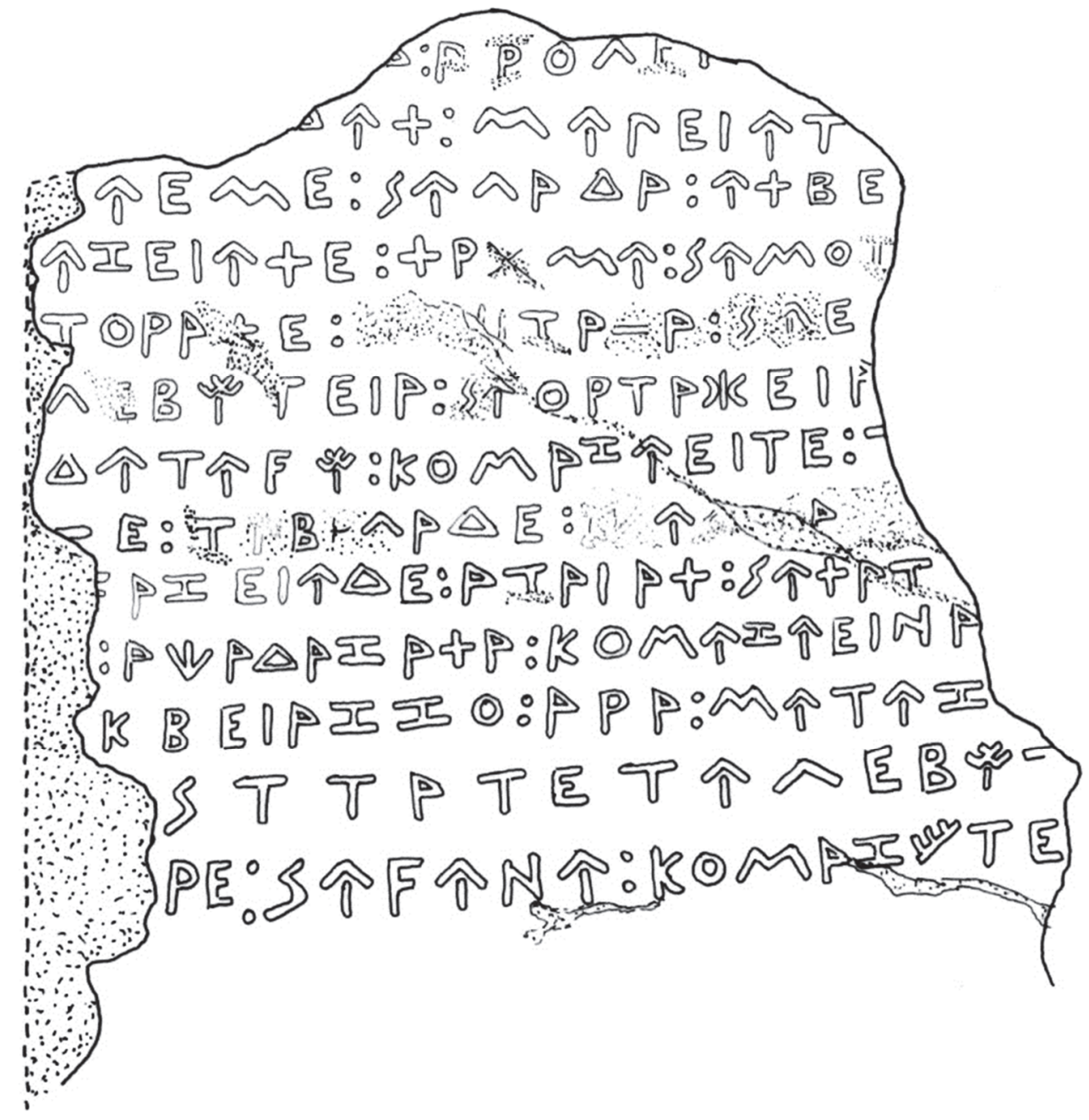

Fig. 40) Ins. No. 1. Facsimile

${ }^{39}$ I first presented the text in "Current Research on Lycian. International Workshop of the Digital Philological-Etymological Dictionary of the Minor Ancient Anatolian Corpus Languages. Institut für Assyriologie und Hethitologie Ludwig-Maximilians-Universität München 16-17 February 2017”. 
Width: $37 \mathrm{~cm}$; Height: $54 \mathrm{~cm}$; Depth: $24 \mathrm{~cm}$. Letters: $3.2 \mathrm{~cm}$ in average.

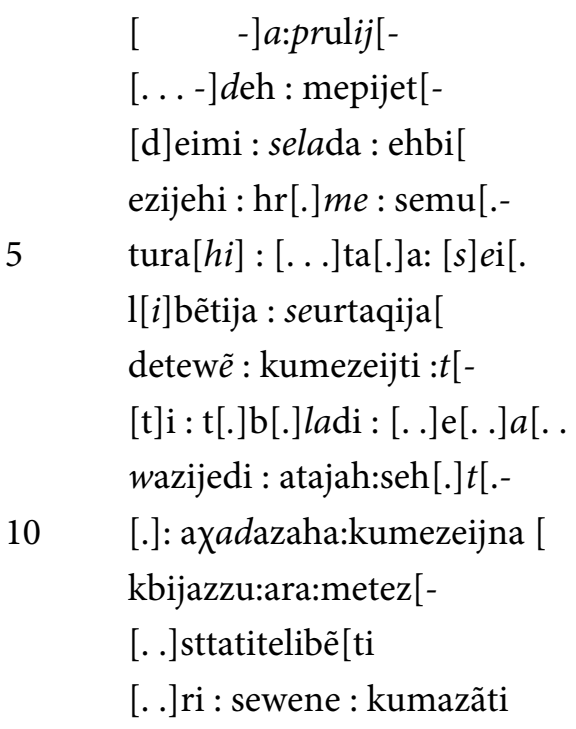

\section{On reading and commentary}

L. 1. Any complete reading of the line seems is hyptothetical as only two letters remained intact, which are $O$ and $\wedge$. The next two signs are not hard to identify. From the first of these signs a vertical stroke making an angle with a horizontal one at the bottom can be traced and it can be identified with E. The reading of the previous two signs, which should be separated from the previous word as tword division marks were used, is problematic. Only vertical strokes of both signs survived and their upper parts are eroded away. In the upper part of the first sign there is a hardly visible trace of a horizontal stroke. Here it may be expected to see an $\Gamma$, if not $T$. The next sign has a round trace attached to the vertical stroke. The expected reading is $P$ or $B$. A interpretation of the signs leads us to identify the word as prulij[-, which may be completed to prulija, as in TL 44b.1(-2) where it appears as ebei : kbija : prulija : êti-pddãt[. . ]/ ijãnatija, being in agreement with $k b i$ - "(an)other" ${ }^{\prime \prime}$. Only the final letter with a small triangle on the left upper side has survived from the word before the word division marks, and it can be identified as $\mathrm{P}$. It seems likely to see here an ebeija, to be compared with ebeija erublija in TL 26.1, ebeija [Xr] uwata in TL 40.1 and ebeija erawazija in TL 117.1 or ebeija arawazija in N303.1 $1^{41}$. The meaning of Prulija in TL 44b.1 depends on contextual analysis. The following word in line 2 is ijãna, identified with the adjective meaning Ionian ${ }^{42}$, combined with the relative form $t i j a$, and it is supposed that ijanna was an attribution to prulija $a^{43}$. The phrase has been interpreted as if it was something or some action with Ionia ${ }^{44}$ or against Ionia ${ }^{45}$. In the present attestation it seems that prulij[a] goes with

${ }^{40}$ Meriggi 1929, 441-442; Neumann 2007, 286; Cau 2003, 51-52; Schürr 2007, 118-122 and Schürr 2009, 164-165.

${ }^{41}$ Neumann 2007, 46.

${ }^{42}$ Since Savelsberg 1874, 9 and doubts of Kalinka in p. 99.

${ }^{43}$ Meriggi 1937, 506.

${ }^{44}$ Gusmani 1961, 43 n.3; Carruba 1977, 300, “qui altri prulija ionii nel temenos templare”; Melchert 2002, 249, "Here on the spot [i.e. the Xanthos Stele] (are) other trophies which are Ionian". Hajnal 1997, 56 , “andere prulija auf dem Feld, welche ionisch (sind)".

${ }^{45}$ Meriggi 1980, 224, "qui (seguono) altre prodezze, che [si compirono? o sim.] contro? gli Joni”. 
[ebeij]a, the demonstrative pronoun in the nom. or acc. pl. case. As the following line includes the verb pija-, the meaning would be to give/ to pass on/to transfer/ to assign or similar actions to third party in order to sell it or to third person in order to assign its rights under a contract. This makes it incompatible with the context of TL $44 \mathrm{~b} .1-2^{46}$. If the word to read in first line is not prulija, one should expect to find a personal name. If so, the beginning of the inscription must include one or two other missing lines.

L. 2. It is possible that the initial word of the line belongs to a parental name ending in - $h$, in gen. sg. Probably the previous line contained the name of builder of the monument with a formula like "X, son of Y". After the word separation mark the text continues with mepijet [- which can be divided into me and pijet [-. Me is an enclitic conjunction introducing the initial components of the sentence. Pijet [- is obviously a predicate and it is very likely to be present $3^{\text {rd }}$ pers. pl. or preterit $3^{\text {rd }}$ sg. pers. of the verb pija- " $\delta l \delta o ́ v \alpha l$ " which is mostly attested with transitive (acc.) and intransitive (dat.) objects ${ }^{47}$. However, the preserved part of the text in lines 3 and 4 continues with a group of parental names in the nominative case, as follows: [-d]eimi : se-lada : ehbi[...

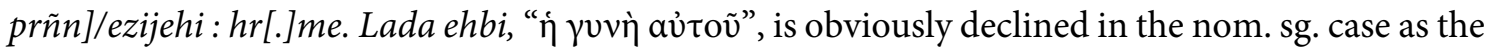
previous word should be completed to read tideimi "vióc" in the nom. sg. or pl. case. If the reading is accepted as a final part of tideimi one expects to see a personal name as the name of the son and then another personal name as the name of the father in the previous line. This interpretation changes the expected dimensions of the inscription and implies that its size was almost double that which is preserved. The following word in 1.4 ends in -ezijehi and can be completed to prñnezijehi, "oikeĩoc", in nom. sg., a word which is always preceded by a personal name in the genitive case, as attested in TL 1, 6, 28, 116 and 150. The reconstruction of line 3 should be something like [ti-/d]eimi : se-lada: ehbi[:se-PN-h+prñn]/-ezijehi. The approximate number of signs in line 3 would be about 25 or more, of which only 15 are preserved. The word which follows prĩnezijehi is read as $h r[] m$.$e , which may be completed to h r[\tilde{m}] m e$. One should be reminded that the reading of the word is not certain. The initial two signs are recognizably $+P[-$ and the last two seem to be - $M \uparrow$, at least, as well as I was able to read it. Normally prñnezijehi appears to be mentioned in the final part of a funerary text, where the tomb owner declares his family relationships, and it comes mostly as the final word of the sentence. Only in two examples does the sentence continue after prñnezijehi. In TL 150.3 and TL 6.2 it is still the final element of the relationships, but in TL 150.3 it was written immediately before the predicate of the first sentence, prñnawate-ti, and before the permitted deceased, hrppi lada ebttehe se tideime. In TL 6.2. it seems probable that $h r[\tilde{m}] m e$ might be dat.-loc. pl. form of hrm̃mã /hrĩmada, "land section, temenos" 48 but the context of the sentence remains quite uncertain as it is difficult to explain what a family has got to do with a temenos. If it is the last element of the sentence it should indicate the reason why person $\mathrm{X}$, son of $\mathrm{Y}$, and his wife and household of $\mathrm{Z}$ gave it. Otherwise, it can be connected with the following se.

The line goes on with semu[.- It can be divided into se, coordinating with $\mathrm{Hr}[\tilde{m}] m e$, and $M u[.-$ which may be the initial part of a personal name. At the very end of the line there is a weak trace belonging to a vertical stroke.

\footnotetext{
${ }^{46}$ Cfr. Melchert 2002, 248-249.

${ }^{47}$ Laroche 1979, 66.

${ }^{48}$ Neumann 2007, 101 and Melchert 2003, 25.
} 
L. 5 begins with -tura[hi] which may be completed to [Qñ]/tura[hi], attested already in TL $59.1^{49}$

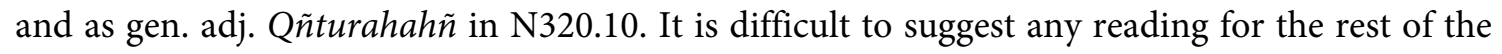
line.

L. 6. l[i]bẽtija:seurtaqija [. The second sequence after the word separation mark includes a personal name, and it should be divided into se-Urtaqija, also attested in the TL 25 bilingual from Tlos, where the person seems to be daughter of Krupsse and Tikeukẽpre. It is an ancient Anatolian

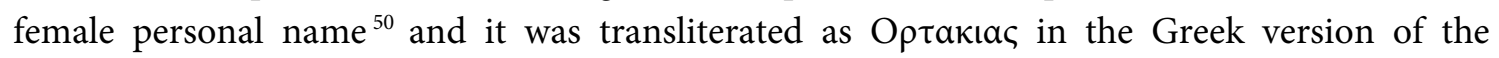
bilingual ${ }^{51}$. The word ending in -l[i]bẽtija at the beginning of the line seems to be a part of personal name, likely a female name. If not, see the commentary on line 12.

L. 7. -detewẽ : kumezeijti : $t$ [ seems to be parallel to medetew[ẽ] kumezeiti in TL 84.5 and medetewẽ

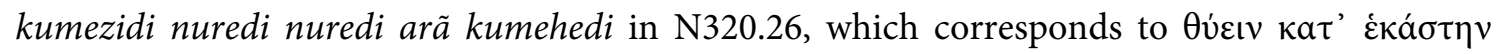

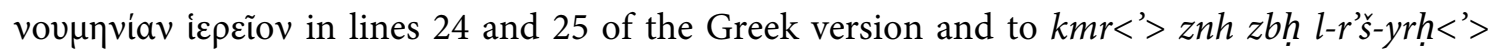
$n q w h$ in lines 14 and 15 of the Aramaic version of the Letoon trilingual ${ }^{52}$. It is obvious that both versions omitted to translate the Lycian medetewe conglomeration group, which can be divided into me-de-te-wẽ enclitics ${ }^{53}$. It appeares three times, including the last one, before the verb kumezi" $\theta \dot{\varepsilon} \varepsilon v$ " and once before the verb smma- in N324.20 $0^{54}$ but, as each of the enclitic particles of the group is attested separately as a component in other conglomeration groups and verbs, it is unlikely that the conglomeration group was firmly linked with the verbs kumez(e)i- and simma. The use of the particle -wẽ with kumez(e)i- occurs repeatedly ${ }^{55}$ and it is not replaced with the particle -we-. The particles -we- and -wẽ should be considered separately as they do not share any common pattern ${ }^{56}$. The particle -we- appears as a second element of the enclitics introducing the sentence, mostly after $s e$ - "and", as it recurs in line 13 , which is the last sentence of the text, and goes on as sewene:kumazãti $i^{57}$. We- seems to be a particle of direct speech ${ }^{58}$.

Kumezeijti, pres. 3 pl. It is always attested in the form of kumezeiti as in TL 26.16, 44b.39, 84.5 and 149.11 and does not represent a typical treatment of yod (I) in the Lycian texts. It recurs in line 10

\footnotetext{
${ }^{49}$ Now a new attestation in Korkut - Tekoğlu 2019, 173-174.

${ }^{50}$ Zgusta 1964, \$ 1114-1.

${ }^{51}$ TAM I 25, 13.

${ }^{52}$ Laroche 1979, 59.

${ }^{53}$ Laroche 1979, 72. cfr. $\mathrm{m}=$ ede=te=wẽ in Melchert 2003, 78; me-de-tewẽ in Schürr 2009, 158; medetewẽ (?) in Bryce 1986, 93 but, me-de-tew[ẽ] for TL 84.5 in p. $69 \mathrm{ff}$.

${ }^{54} \dot{\alpha} \mu \alpha \rho \tau \omega \lambda$ ò $\varepsilon^{\prime} \sigma \tau \omega$ for the equivalent of pdde ... sm̃mati in N320.37-38, "être responsable devant" in Laroche 1979, 75.

${ }^{55}$ [. . . .- ] $[$ [ew]ẽ: kumezeiti: in 65.21 and ] medewẽ-emu:kumezeiti-ti: in 44b.39 (cfr. TL bedewẽ emu cumezeititi; F ]bedewẽ emu: cumezeiti ti; Melchert, Corpus, s]e=be dewẽ emu: kumezeiti=ti; Schürr 2012, 118 u?]be dewẽ emu: kumezeiti-ti; Lebrun 1999, 49 ti]be-dewẽ-emu:kumezeiti-ti) can be added to the attestations (TL 84.5 and N320.26) mentioned above. The particle -wẽ was not used with kumez(e)i- in TL 26.16, 44b.44-45, 65.12, 149.11 and 17, 150.9, N324.16/17.

${ }^{56}$ Cfr. Neumann 2007, 420 and Melchert 2003, 78.

${ }^{57}$ The particle -we- occurs in some models such as se+we+predicate in 44a.16 (:sewe:maxã:), 102.3 (:sewe:tubidi:) or me+we+predicate in 91.3 (me-we-j-esu:), se+we+pronouns/adverbs/negation+predicate in 45b.5 (se-we-ne-xttaiti), 44b.50 (se-we-nepe:astte:), 324.28 (se-we-hri-xladi), 45a.6 (-se-we-ñte:k[...).

${ }^{58}$ Gusmani 1968, 15 fn. 74.
} 
in the infinitive form kumezeijna instead of the regular kumezeine, as in TL 44b.44-45, 149.17, 150.9 , and exceptionally kumezeini in TL 65.12. Normally the Lycian yod is an intervocalic sound serving to divide words or morphological components like se-j-atli in 37.6, me-we-j-esu in 91.3 etc ${ }^{59}$. Besides, it appears to be inserted in synaeresis with $i+-a /-\tilde{a}_{\text {,-e/-e }},-\mathrm{u}\left(-i j a-,-i j \tilde{a}-,-i j e^{60}-,-i j \tilde{e}-,-\right.$ $i j u-), a+-a,-e\left(-a j a^{61}-,-a j e-\right), e+-e /-\tilde{e},-i\left(-e j e-,-e j \tilde{e}-,-e j i^{62}-\right)$, but in diaeresis before $-u$ such as Tikeukẽprẽ (TL 25a.5), Piñteusi (N 3061 and 2), Edrijeusehñ ( TL 29.5), Ijaeusas (TL 44a.52), Ñtarijeusehe (TL 44b.59), Mlejeusi (TL 139.5) and even se-uhazata (N 320.27) ${ }^{63}$. Kumezeijti and kumezeijna are exceptions as -ei- was never documented with the insertion of yod before consonants, ${ }^{64}$ but before vowels ${ }^{65}$. It is highly probable that $-e i$ - as a diphthong in the present attestations was written with the insertion of yod to express the pronunciation way of the words.

L. 8. It is difficult to suggest any restoration of the hardly recognizable signs in this line.

L. 9 begins with -wazijedi which seems to be abl.-instr. of arawazija or erawazija, equated with tò $\mu v \tilde{\eta} \mu \alpha$ in TL 117 bilingual.

The next word is atajah, very likely a personal name in genitive case, otherwise unknown in the Anatolian and the Greek personal names repertory. The final of the line includes the signs which may be divided into se-h[.]t[. It seems plausible to see another personal name in genitive case connecting Atajah with se- conjunction. It is difficult to identify the sign following $h$-. It may be $P$ or $P$. The next sign seems to be $T$ but not certain.

L. 10 has been read as axadazaha:kumezeijna.

axadazaha is declined in nom.-acc. nt. pl case and is the adj. gen. for axadaza, which seems to be divided into axa-d-aza- or axad(a)-aza. It may be related with axãtaza, who is a kind of priest for Malija Wedrẽñni in TL $149.3^{66}$. A Xadazaha expresses no doubt the elements, animals or objects at the disposition of or belonging to the axadaza in order to realize a sacrifice, as it is followed by the infinitive kumezeijna. The phonetic and morphological change from axãtaza to axadaza seems to be unknown, unless the nasalised $\tilde{a}$ was followed by a tenuis consonant.

L. 11 goes on with kbijazzu:ara:metez[-. Kbijazzu is a new entry for the Lycian vocabulary. It is not certain if it represents an entire word or should be divided into kbi-j-azzu. Both kbi and azzu seem to be in agreement with acc. sg. case. Its relation with azza-lã, acc. sg., in TL 44c,10 and azza-

\footnotetext{
${ }^{59}$ Neumann 1969, 376; Melchert 1994, 297; Hajnal 1995, 13-15. Cfr. Bryce 1987, 91.

${ }^{60}$ Exception Pubieleje $=\Pi v \beta \iota \alpha \lambda \eta \iota$ in TL 117.4-5.

${ }^{61}$ Exception Zzajaah in TL 103.2

${ }^{62}$ A unique attestation is found in $\mathrm{N} 313 \mathrm{f}$.

${ }^{63}$ Laroche 1979, 81-82.

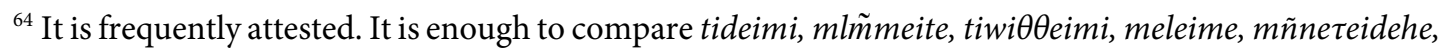

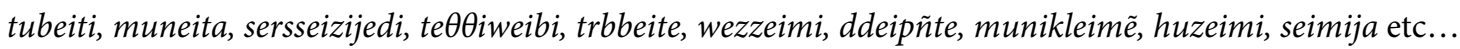

${ }^{65}$ Exeteija ('Eкатаĩoৎ), kebeija.

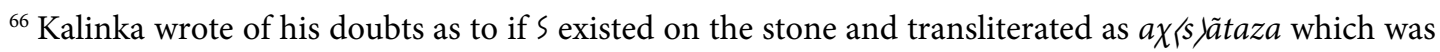

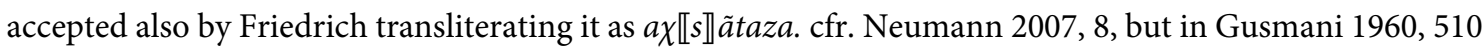
fn. 52: "uomo di rango, maggiorente"; Neumann 1967, 36: "Priester, Verehrer, Schutzbefohlener"; Meriggi 1979, 251: “Oberpriester”; Bryce 1980, 49: “a priest”; Lebrun 1987, 151: “une catégorie de prêtres”; Melchert 2003, 7: “priest for animal sacrifices".
} 
lãi, nom. pl. or gen. sg., in TL 44b,59 is not certain. It is followed by ara in uncertain case. It is obvious that kbijazzu and ara are not in agreement. The acc. sg. case of ara was one of the words not translated into Greek in N 320,27 and interpreted as an adjective and adverb ${ }^{67}$. In the present text. ara cannot be an adjective or a transitive object. The line continues with metez[- a puzzle with possible divisions into me-tez[-, me-t-ez[-, or me-te-z[-.

L. 12 has the reading: [. .]sttatitelibe [- which should be divided as sttati-teli-b-ẽ or it may be completed to sttati-teli-b-ẽ $\left[t i(?)^{68}\right.$.

The text ends probably with a negation in 1.13 where [. .]ri : sewene : kumazãti comes as the last sentence. Kumazãti is undoubtedly a verb in pres. pl. 3 meaning "to perform priestly duties"69. The initial signs of the line may take part of a word like te]ri or tite]ri, or tuwe]ri.

It is a hard task to define the typology of the monument and the context of the inscription. At first sight it does not seem to have been an object belonging to typical funerary monuments and their architectural elements, but in line 9 the type of monument was probably defined as arawazija, which was employed also for funerary monuments. It is a stone block possibly placed in an area of religious character. Its estimated dimensions seem to be 70 or $80 \mathrm{~cm}$ in width, $60 \mathrm{~cm}$ in height and $24 \mathrm{~cm}$ in depth. The text confirms strongly the religious character of the monument. The verb kumez(e)i- "to sacrifice, worship" is mentioned twice, and the last sentence of the text has the verb kumaza- "to perform priestly duties, to be priest". No reference to any animal or object name, or any period for the sacrifice is preserved, but the sacrifice was under the disposition of a priest named axadaza. From the analysis of some sporadic words it is understood that activities have a ritual character to be performed where the monument was placed (sttati-teli-b-ẽ [ti). The text moreover includes a series of personal names both female and male. The owner's and his family members' names were not preserved but they assigned (pijet[ẽ] instead of pijẽtẽ) it, if prulija, to third party. The following readings may be associated with personal names: 1. 2: - ]deh; 1. 4: se-Mu[; 1. 5: Qñ]tura[hi]; 1. 6 -]l[i]bẽtija; 1. 6: se-Urtaqija; 1.9 Ataja; 1. 9: se-H[.]t[-. The names may be the reason why the religious activities need more than two or three persons when they perform priestly duties. Their role seems to function as a group of priestly community, serving the sacred place, funeral or religious, performing sacrifices and possibly staging small festivals or rituals. The text ends with a negation under uncertain conditions.

\section{No. 2) Hamlet of Sazak - Araxa or Kadyanda}

This rock-cut tomb with an inscription in the Lycian language is located in the hamlet of Sazak on the left side of the road from modern Yeşilüzümlü (near Kadyanda) to Ortaköy (a modern village near Araxa), almost $7 \mathrm{~km}$ from Kadyanda and $5 \mathrm{~km}$ from Araxa (Fig. 43-Fig. 46)..$^{70}$ Though

\footnotetext{
${ }^{67}$ Laroche 1979, 72: ara “juste, fas”, arã “rituellement”.

${ }^{68}$ For a detailed analysis of the verb stta- see Schürr 2014, $141 \mathrm{ff}$.

${ }^{69}$ Cfr. Melchert 2003, 33: “be a priest”; Hajnal 1995, 84: “er ist Priester”. See also Bryce 1986, 78: “become sacrificer" and Neumann 2007, 176 doubts on the verb.

70 The discovery of the inscription was first reported by Max Gander in a private letter to me, and it was planned to publish it with him. This could not be done, because an official permission either from Fethiye Museum or from the Ministry of Culture and Tourism is required to publish the tomb and its inscription. At the same time the survey team headed by Fatih Onur, who has an official permission for epigraphic
} 
already reported by earlier researchers, ${ }^{71}$ it was never published. The inscription was incised on the façade of the rock-cut tomb (Fig. 44-Fig. 45) and has 6 lines. No word division marks were employed in the text, but spaces were left between the words.

Measures:

Width: $160 \mathrm{~cm}$ till to the last sign; Height: $23+12 \mathrm{~cm}$. Letters: $2.5>3 \mathrm{~cm}$.

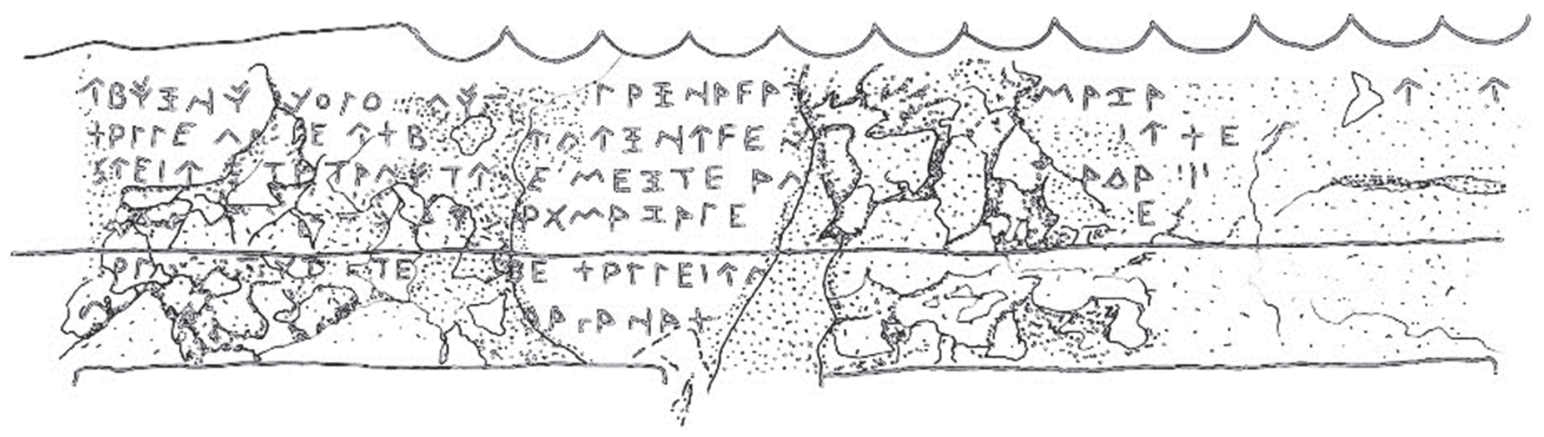

Fig. 41) Ins. No. 2. Facsimile

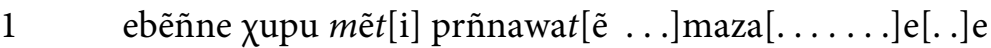

hrppi ladi ehb[i ses]edeñnewi $\chi[$ ñnahi ehbi]jehi[se prñnezi atlahi]

seije ñta tadẽ te[s]i miñti al[adahali] ada III [ ... (?)]

mei [ñtep]i tadẽ arm̃mazapi[mi se ladã ehb]i [se ...(?) seijene]

$5 \quad[\mathrm{~h}] \mathrm{rp}[\mathrm{pi}]$ tãt $[\mathrm{u}]$ ti[ke k]bi hrppijem[ei tadi tike tike ... (?)]

$m$ [en]e [tubeiti ẽni] mahanahi [se itlehi trm̃mili huwedri]

\section{On reading and commentary:}

The present text has the typical structures of sepulchral inscriptions in the Lycian language. It begins with the standard introduction mentioning the tomb owner's name probably with paternal lineage and the aim of construction. The second stage is the mention of an institutional price in the ada formula $\mathrm{a}^{72}$. The third includes rules for authorized and unauthorized burials. The fourth concerns the violation of the tomb, and the last is the penalty mechanism or vengeance.

The name of the tomb's owner and his father's name were not preserved, only four letters, being read as -maza- in the 1st line, who should be identical with Arm̃mazapi[ in line 4. Armmazapi[seems to be one of the personal names composed with the Anatolian arma- ${ }^{73}$ and may be

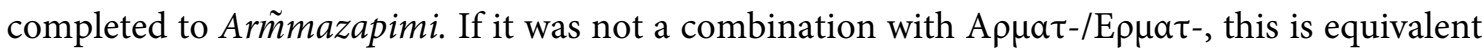

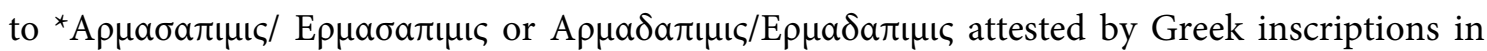
Asia Minor ${ }^{74}$.

surveys in the area informed me about his new findings including this new one, which finally took its place in this contribution.

${ }^{71}$ Fellows 1841, 123; Spratt - Forbes 1847, I, 40; Ritter 1859, 1000 and Schweyer 1996, 19.

${ }^{72}$ Christiansen 2020, $166 \mathrm{ff}$. for an analysis of the formula. See also Melchert 2015, $154 \mathrm{ff}$. and Schürr 2008, $147 \mathrm{ff}$.

${ }^{73}$ Houwink ten Cate 1961, 132 ff. and Neumann 2007, 70.

${ }^{74}$ Cfr. Colvin 2004, 75 and Balzat 2014, 271. For lydian arm-ta cfr. Gérard 2005, 88 fn. 555. 
The construction of the tomb was dedicated to his wife and grandmother's successive generation, ${ }^{75}$ and possibly for his own household. The restoration of the line could continue with hrppi ladi ehb[i s-es]edeñnewi x[ñnahi ehbi]jehi [se prñnezi atlahi]. Normally esedeñnewi and prĩnezi were not mentioned together among the deceased or members who had right to be buried, ${ }^{76}$ but it has been pointed out that in TL 36, 5-7 the upper ñtata was given to his wife and to the successive generation of Mñneteide, and lower $\tilde{n}$ tata was given to his own household ${ }^{77}$. Otherwise, all the family members including himself and children should be expected to be mentioned in the line, as in TL 108.

The text continues with a standard payment formula seen in sepulchral inscriptions ${ }^{78}$ : se-ije ñta tadẽ te[s]i miñti al[adahali] ada III. It is very hard to say if the text continues after 3 ada in the line. No trace of any further sign was identifiable.

The third part of the text should cover legal and illegal uses of the tomb. The owner of the tomb, Armmazapi[mi], and his family members must be mentioned as right owners with the control over the property, banning anyone else from burying without permission. The text may have carried statements like : mei [ñtep]i tadẽ Arm̃mazapi[mi se ladã ehbi se ... seijene]/[h]rp[pi] tãt [u] ti[ke k]bi, "they put inside Armmazapimi [and his wife and his..... and let them not] put inside another one".

Then the text ends in giving names of those responsible in the case of violation: hrppijem[ei tadi tike tike (... ?)] / m[en]e [tubeiti ẽni] mahanahi [se itlehi trmmili huwedri]. The final line of the inscription is badly eroded but mahanahi in the survived part of the stone still remains recognizable. It should be interpreted as ẽni mahanahi, "mother of god(s), Leto" " but does not mention the vengeance gods such as mãhãi huwedri, trqqas, marazija miñtaha, muhãi miñtehi, malija wedrẽ̃nni besides the common itlehi trmmili huwedri. Leto is defined a vengeance goddess

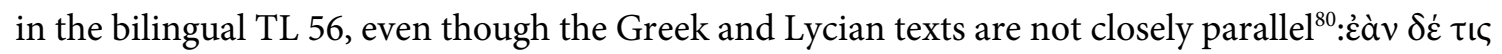

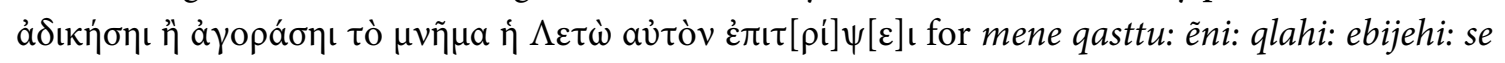
wedri: wehñtezi.

\section{Bibliography}

Akyürek Şahin et al. 2017 N. E. Akyürek Şahin - F. Onur - M. Alkan - M. E. Yıldız, Surveys on the Transportation Systems in Lycia/Pamphylia 2016 - Likya/Pamfilya Ulaşım Sistemleri Yüzey Araştırması 2016, ANMED 15, 2017, 203212.

Akyürek Şahin et al. 2018 N. E. Akyürek Şahin - F. Onur - M. Alkan - M. E. Yıldız, Likya/Pamfilya Ulaşım Sistemlerinin Epigrafik ve Tarihi Coğrafik Açılardan

\footnotetext{
${ }^{75}$ Schweyer 2002, $190 \mathrm{ff}$. and Bryce 1986, 147.

${ }^{76}$ See TL 39, 41 and 108.

77 TL 36, 5-7: se pijetẽ: hrzzi: ñtatã: ladi: ehbi: se-mñneteidehe/ esedẽñnewi ) se pijetẽ: ẽtri: ñtatã: prñnezi/ atlahi.

${ }^{78}$ Bryce 1976, 175.

${ }^{79}$ Laroche 1957, 190 and Laroche 1980, 4.

${ }^{80}$ Bryce 1983, 2 and 10.
} 
Araştırılması 2015 ve 2016 Yılları Sonuçları, Araştırma Sonuçları Toplantisı 35, 2018, 387-410.

Balzat 2014

Barth 1850

Bean 1958

Bean 1976a

Bean 1976b

Benndorf - Niemann 1884 O. Benndorf - G. Niemann, Reisen im südwestlichen Kleinasien. Vol. I, Reisen in Lykien und Karien, Vienna 1884.

Bryce 1976

Bryce 1980

Bryce 1983

Bryce 1986

Bryce 1987

Buschmann 1993

Bürchner 1919

Carruba 1977

Cau 2003

Christiansen 2020

Çeker 2016

Colvin 2004

Davies 1895

J. S. Balzat, Names in EPM-in Southern Asia Minor. A contribution to the cultural history of Ancient Lycia, Chiron 44, 2014, 253-284.

H. Barth, Auf Reisen durch die Küstenlandschaften des Mittelmeeres gesammelte Inschriften. Rheinisches Museum für Philologie 7, 1850, 246-270.

G. E. Bean, Die Lage von Phellos, Anz. ÖAW 95, 1958, 49-58.

G. E. Bean, Kalynda, in: R. Stillwell - W. L. Macdonald (edd.), The Princeton Encyclopedia of Classical Sites (PECS), Princeton 1976, 434.

G. E. Bean, Pasanda, in: R. Stillwell - W. L. Macdonald (edd.), The Princeton Encyclopedia of Classical Sites (PECS), Princeton 1976, 679.

T. R. Bryce, Burial Fees in the Lycian Sepulchral Inscriptions, Anatolian Studies 29, 1976, 175-190.

T. R. Bryce, Sacrifices to the dead in Lycia, Kadmos 19,1, 1980, 41-49.

T. R. Bryce, The Arrival of the Goddess Leto in Lycia, Historia 31, 1983, 1-11.

T. R. Bryce, The Lycians in Literary and Epigraphic Sources, Copenhagen 1986.

T. R. Bryce, Some observations on the pronunciation of Lycian, Kadmos 26, 1987, 84-97.

K. Buschmann, Hızırlık bei Fethiye: Das altlykische Telebehi, AST 10, 1993, 429-437.

L. Bürchner, Kalynda, in: RE 20/X. 2, 1771-1172, 1919.

O. Carruba, Commentario alla trilingue Licio-Greco-Aramaica di Xanthos, Stud. Micen. ed egeo-anatolici 18, 1977, 273-318.

N. Cau, Note Sulla Stele Di Xanthos: Tl 44B, 11-23 E 47-57, Kadmos 42, 2003, 50-64.

B. Christiansen, Grave Matters. Legal Provisions for a Proper Final Rest in Classical Lycia, in: M. Zimmermann (ed.), Das Xanthostal in archaisch-klassischer Zeit. Eine archäologisch- historische Bestandsausnahme, Göttingen 2020, 166-261.

A. Çeker, Doğal Ortamın (Jeomorfoloji-Hidrografya) Tarımsal Faaliyetlere Etkileri Bağlamında Bir Alan İncelemesi: Dalaman Ovası Örneği, Yenifikir 16, 2016, 29-50.

S. Colvin, Names in Hellenistic and Roman Lycia, in: S. Colvin (ed.), The Greco-Roman East, Cambridge 2004, 44-84.

G. Davies, Greek Inscriptions from Lycia, JHS 15, 1895, 100-115. 
Doğu 1988

Fellows 1841

Gérard 2005

Godley 1920

Gusmani 1960

Gusmani 1961

Gusmani 1968

Hajnal 1995
French 2014

Hajnal 1997

A. F. Doğu, Köyceğiz-Dalaman Çevresindeki Tarihi Yerleşme Alanlarının Jeomorfolojik Birimlerle İlişkisi (Güneybatı Anadolu), Ankara Üniversitesi Dil ve Tarih-Coğrafya Fakültesi Derg. 32, 1-2, 1988, 319-328.

C. Fellows, An account of discoveries in Lycia, being a journal kept during a second excursion in Asia Minor, London 1841.

D. H. French, Roman Roads and Milestones of Asia Minor Vol. 3: Milestones, Fasc. 3.5: Asia, London 2014.

R. Gérard, Phonétique et morphologie de la langue lydienne, Louvain-la-Neuve 2005.

A. D. Godley (ed.), Herodotus, Cambridge 1920.

R. Gusmani, Concordanze e discordanze nella flessione nominale del licio e del luvio, Rend. Ist. Lomb. di Scenze e Lett. 94, 1960, 497-512.

R. Gusmani, Il sufisso -tio- di aggettivi "locali" e la sua diffusione nelle lingue indo-europee, Ann. dell'Istituto Orient. di Napoli 3, 1961, 4148.

R. Gusmani, Zur Deutung einiger milyischer Wörter, Arch. Orientální 38, 1968, 1-18.

I. Hajnal, Der lykische Vokalismus, Graz 1995.

I. Hajnal, Definite nominale determination im Indogermanischen, Indogermanische Forschungen 102, 1997, 213-239.

Heberdey - Kalinka 1897 R. Heberdey - E. Kalinka, Bericht über zwei Reisen im südwestlichen Kleinasien, Vienna 1897.

Hellenkemper - Hild 2004 H. Hellenkemper - F. Hild, Lykien und Pamphylien I-III (Tabula Imperii Byzantini 8; Österreichische Akademie der Wissenschaften. Philosophisch-historische Klasse. Denkschriften 320), Vienna 2004.

Hoskyn 1842

R. Hoskyn, Narrative of a Survey of Part of the South Coast of Asia Minor; And of a Tour into the Interior of Lycia in 1840-1; Accompunied by a Map, J. R. Geogr. Soc. London 12, 1842, 143-161.

Houwink ten Cate 1961 P. H. J. Houwink ten Cate, The Luwian population groups of Lycia and Cilicia Aspera during the Hellenistic period, Leiden 1961.

Jameson 1974

S. Jameson, Kalynda, in: RE Supp. 14, 214, 1974.

Jones 1924

Kaletsch 1999

Karabulut 2019

H. L. Jones (ed.), The Geography of Strabo, London 1924.

H. Kaletsch, Kalynda, in: DNP 6, 214, 1999.

B. Karabulut, Batı Lykia'da Oktapolis'in Politik Yapısı, in: N. E. Akyürek Şahin - M. E. Yıldız - F. Avcu (eds.), Eskçağ Yazıları 13 [AKRON 17] İstanbul 2019. 69-96.

Köktürk - Milner 2003 H. Köktürk - N. P. Milner, A land dispute from the Lycian borderland, Anatol. Stud. 53, 2003, 131-138.

Korkut - Tekoğlu 2019 T. Korkut - R. Tekoğlu, Tlos Antik Kenti Qñturahi Kaya Mezarı, Olba 27, 2019, 169-188. 
Laroche 1957

Laroche 1979

Laroche 1980

Lebrun 1987

Lebrun 1999

Marek 2006

Melchert 1994

Melchert 2002

Melchert 2003

Melchert 2015

Meriggi 1929

Meriggi 1937

Meriggi 1979

Meriggi 1980

Neumann 1967

Neumann 1969

Neumann 2007

Nollé - Sayar 1983

Onur 2016

Pons - Edelman 1963
E. Laroche, Comparaison du louvite et du lycien, Bull. la Société Linguist. Paris 53, 1957, 159-197.

E. Laroche, La stèle trilingue du Létôon. Fouilles de Xanthos. Fouilles de Xanthos VI, Paris 1979.

E. Laroche, Les dieux de la Lycie classique d'apres les textes lyciens, in: H. Metzger (ed.), Actes du colloque sur la Lycie antique, Istanbul, 1977 Paris 1980, 1-6.

R. Lebrun, Notes Lyciennes, Hethitica 7, 1987, 149-160.

R. Lebrun, Studia Lyciaca, Hethitica 14, 1999, 43-53.

C. Marek, Die Inschriften von Kaunos, Munich 2006.

H. C. Melchert, Anatolian Historical Phonology, Amsterdam-Atlanta 1994.

H. C. Melchert, The God Sanda in Lycia?, in: Silva Anatolica, Anatolian studies presented to Maciej Popko on the occasion of his 65th birthday Warsaw 2002, 241-251.

H. C. Melchert, A Dictionary of the Lycian Language, Ann ArborNew York 2003.

H. C. Melchert, Lycian alaha- and alada/ehali-, in: E. Dupraz - W. Sowa (eds.), Genres épigraphes et langues d'attestation fragmentaire dans l'espace méditerranéen, Mont-Saint-Aignan 2015, 153-162.

P. Meriggi, La declinazione del Licio I, in: Rendiconti della classe di Scenze morali, storiche e filologiche, ser. VI, vol. IV, 7-10, Rome 1929, 410-450.

P. Meriggi, Zur Xanthosstele, Acta Jutl. 9, 1937, 504-517.

P. Meriggi, La declinazione del Licio II, Acad. Naz. dei Lincei, Rend. della Cl. di Sci. morali, Stor. e Filol. 24, 3, 1979, 243-268.

P. Meriggi, La declinazione dei nomi propri e dei pronomi in licio, Stud. Micen. ed Egeo-Anatolici 20, 1980, 215-274.

G. Neumann, Beiträge zum Lykischen III, Die Sprache 13, 1967, 3138.

G. Neumann, Lykisch, in: B. Spuler (ed.), Altkleinasiatische Sprachen, Handbuch der Orientalistik 1.2.1/2.2 Leiden 1969, 358-396.

G. Neumann, Glossar des Lykischen. Überarbeitet und zum Druck gebracht von J. Tischler, Wiesbaden 2007.

J. Nollé - M. H. Sayar, Drei Inschriften aus Antiphellos in Lykien, ZPE 52, 1983, 219-223.

F. Onur, Parerga to the Stadiasmus Patarensis (16): The Roads, Settlements and Territories, Gephyra 13, 2016, 89-118.

L. J. Pons - C. H. Edelman, A Soil Survey of the Köyceğiz-Dalaman Area (Turkey), Ankara 1963. 
Ritter 1859

Robert 1937

Ross 1845

Şahin 2014

Şahin - Adak 2007

Savelsberg 1874

Schürr 2007

Schürr 2008

Schürr 2009

Schürr 2012

Schürr 2014

Schweyer 1996

Schweyer 2002

Spratt - Forbes 1847

Stemler 1909

Takmer 2007

Tietz 2003

Walpole 1820

Way 1913

Zgusta 1964
C. Ritter, Die Erdkunde im Verhältniß zur Natur und zur Geschichte des Menschen oder allgemeine, vergleichende Geographie (Vol. IX), Berlin 1859.

L. Robert, Etudes anatoliennes. Recherches sur les inscriptions grecques de $\Gamma$ Asie Mineure, Etudes orientales 5, Paris 1937.

L. Ross, Lycische Grabschriften, Intelligenzblatt zur Allgem. Litt. Zeit., 1845, 289-296 (no. 36).

S. Şahin, Stadiasmus Patarensis. Itinera Romana Provinciae Lyciae. Lykia Eyaleti Roma Yolları, İstanbul 2014.

S. Şahin - M. Adak, Stadiasmus Patarensis Itinera Romana Provinciae Lyciae, İstanbul 2007.

M. J. Savelsberg, Beiträge zur Entzifferung der lykischen Sprachdenkmäler I, Bonn 1874.

D. Schürr, Zum Agora-Pfeiler in Xanthos I: Anschluß eines Weiteren Fragments, Kadmos 46, 2007, 109-124.

D. Schürr, Zur rolle der lykischen mindis, Kadmos 47, 2008, 147-170.

D. Schürr, Zum Agora-Pfeiler in Xanthos II: Selbstlob auf Perserart und Ordnung des Raumes, Kadmos 48, 2009, 157-176.

D. Schürr, Zum Agora-Pfeiler in Xanthos III: Vom Wettergott und

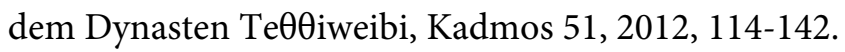

D. Schürr, Ist lykisch stta - ein Erb- oder ein Lehnwort?, Hist. Linguist. 127, 2014, 141-149.

A.-V. Schweyer, Les pays lycien: une étude de géographie historique aux époques classique et hellénistique, Rev. archéologique 1996, Fascicule 1, 1996, 3-68.

A.-V. Schweyer, Les Lyciens et la Mort. Une étude d'histoire sociale. Varia Anatolica XIV, Paris 2002.

T. A. B. Spratt - E. Forbes, Travels in Lycia, Milyas, and the Cibyratis (Vols. I-II), London 1847.

H. Stemler, Die griechischen Grabinschriften Kleinasiens, Strassburg 1909.

B. Takmer, Lex Portorii Provinciae Lyciae. Ein Vorbericht über die Zollinschrift aus Andriake aus neronischer Zeit, Gephyra 4, 2007, 165-188.

W. Tietz, Der Golf von Fethiye, Bonn 2003.

R. Walpole, Travels in various countries of the East: being a continuation of Memoirs Relating to European and Asiatic Turkey, London 1820.

A. S. Way, Quintus Smyrnaeus, The Fall of Troy, Cambridge, MA 1913.

L. Zgusta, Kleinasiatische Personennamen, Prag 1964. 
Zgusta 1984

Zimmermann 1992
L. Zgusta, Kleinasiatische Ortsnamen, Heidelberg 1984.

M. Zimmermann, Untersuchungen zur historischen Landeskunde Zentrallykiens, Bonn 1992.

\section{Fethiye Etrafındaki Antik Yol Hatları ve Yeni Likçe Yazıtlar \\ Öz}

Bu makalenin ilk kısmı Fethiye çevresinde, Pinara, Telmessos, Kalynda, Kadyanda, Araksa ve Tlos kentleri arasındaki antik yolların ve güzergâhların tespiti için son yıllarda yapılan yüzey araştırmalarının sonuçlarını içermektedir. Bu değerlendirmeler çerçevesinde Pinara ve Telmessos arasında birisi Kabaağaç - Gökben üzerinden diğeri de Babadağ üzerinden olmak üzere iki antik yol olduğu tespit edilmiş, Patara Yol Anıtı'nda belirtilen yolun ise Babadağ üzerinden giden yol olması gerektiği önerilmiştir. Tlos ve Telmessos arasındaki yolun Seydikemer üzerinden gitmiş olması beklenen bir durum iken, yapılan incelemeler neticesinde bu yol büyük ihtimalle, sadece bir ayağının temelini tespit edebildiğimiz Allıkavak'taki antik köprüden geçerek Çaltıözü, Bozyer ve Esenköy üzerinden Telmessos'a ulaşmaktaydı. Telmessos ve Kalynda arasındaki yolun büyük oranda bugünkü Fethiye - Dalaman yolunu takip ettiği anlaşılmış ve bu yol üzerinde kalan İnlice'nin Daidala olarak ve Şerefler'in de Kalynda olarak lokalizasyon önerileri yeniden değerlendirilmiştir. Kadyanda ve Telmessos arasındaki antik yolun Eldirek üzerinden gitmiş olabileceğinin daha doğru olduğu, Kadyanda ve Araksa arasındaki yolun ise antik Atlıdere Köprüsü üzerinden gittiği gözlemlenmiştir. Kadyanda ve Tlos arasındaki yolun da aynı köprüyü kullanarak Kıncılar, Girmeler ve Güneşli yakınlarından Tlos'a ulaşması gerekmektedir. Keza, Araksa ve Tlos arasındaki yol da Atlıdere Köprüsü’nün güneyindeki aynı hattı izlemiştir.

Makalenin Likçe yazıtlarının ele alındığı ikinci bölümde biri Pinara'nın yak. 7,5 km kadar kuzeyinde yer alan Asarcık'ta (antik Aloanda), diğeri Kadyanda/Araksa arasındaki yol üzerinde bulunmuş iki yeni yazıt ele alınmıştır. Aloanda yazıtının dinî ve gömü niteliği vardır. Yazıtın neredeyse yarısının ele geçmiş olması nedeniyle tam olarak ne için dikildiği anlaşılamamıştır. Yazıt, Likçe çalışmaları sahasına yeni sözcük ve morfoloji katkıları sağlamaktadır. Yazıt aracılığıyla buluntu yerinin bir kült alanı olabileceği tartışmaya açılmıştır, çünkü yakınında muhtemelen daha geç döneme ait lahit ve kaya mezarları bulunsa da, buluntu alanında Likya dönemine ait gömü izleri bulunmamaktadır. Bu nedenle eğer erken dönemden bir kaya mezarı veya lahit söz konusu değilse anıtın doğrudan bir gömü yazıtı niteliği taşıdığını söylemek zordur. Çalışmada çözümleme ve okuması yapılan ikinci yazıt ise, Likya coğrafyasında örneklerine sıklıkla rastlanan bir kaya mezarının yazıtıdır. Ne yazık ki, yazıt yüzeyinin doğal sebeplerle aşınıp gitmiş olması nedeniyle mezarın kime ait olduğu tam olarak tespit edilememektedir. Varsayımsal olarak bu kişinin Armazapimi adında birisi olabileceği düşünülmektedir. Mezarı bir şahsın kendi eşi, ev halkı ve annesinin soyundan gelenler için inşa ettirdiği okunabilmiştir. Yazıt, gömü kurallarının belirlenmesi yanında, mezarda gömü ihlâli yapılması durumunda Likya'nın çeşitli kurum ve tanrılarına karşı sorumlu olunacağını belirterek sonlanmaktadır. Her iki Likçe yazıtın da açı bir Türkçe çevirisi verilememektedir.

Anahtar Sözcükler: Lykia, antik yollar, Fethiye, Telmessos, Pinara, Tlos, Kadyanda, Araksa, Kalynda, Daidala, Likçe yazıtlar, kaya mezarı, stel, kült, rahip, kurban sunusu, sunak, aile gömüsü. 


\section{The Ancient Road Network and New Lycian Inscriptions around Fethiye Abstract}

The first part of this contribution contains the results of field surveys made in recent years exploring the ancient road network around Fethiye, including the routes between Pinara, Telmessos, Kalynda, Kadyanda, Araxa and Tlos. According to these results, there are two options for the road between Pinara and Telmessos, one through Kabaağaç and Gökben, one over Babadağ. In the article, the second option is suggested for the road recorded in Monumentum Patarense (MP). While the road between Tlos and Telmessos was at first expected to have passed through today's Seydikemer, the field surveys identified a better option with a course through Çaltı̈̈zü, Bozyer ve Esenköy, crossing over an ancient bridge, only a footing-base of which has survived, in today's Allikavak. The ancient route between Telmessos and Kalynda mostly follows the modern road between Fethiye and Dalaman, and the localizations of Inlice/Daidala and Şerefler/Kalynda are discussed again. The road between Kadyanda and Telmessos probably led through Eldirek, and the road between Kadyanda and Araxa passed over the ancient bridge in Atlidere. The route from Kadyanda to Tlos also passed over this bridge and reached Tlos following a course past Kıncılar, Girmeler and Güneşli. Similarly, the road between Araxa and Tlos followed the same route to the south of Atlidere Bridge.

In the second part of the contribution two new Lycian inscriptions are published. One was found at Asarcik (ancient Aloanda) located ca. 7,5 km to the north of Pinara, and the other on the road between Kadyanda and Araxa. The inscription from Aloanda reflects a religious and funerary content. The type of monument cannot be identified with certainty, because half of the stone is missing. The discussion of the inscription has contributions concerning the vocabulary and morphology of the Lycian language. The find spot of the inscription might have been a religious location, because there are no funerary remains from the Lycian period in the spot. It is less likely that inscription has a funerary character, as there was no rock-cut tomb or early sarcophagus at the find spot, though there are several later funerary monuments of these types nearby. The second inscription has the usual content of Inscribed Lycian rock-cut tombs, of which there are many examples. The tomb's owner cannot be identified for certain, due to the natural erosion of the inscription surface, but the name may be conjectured as be Armazapimi. The owner built the tomb for himself, his wife, his household and for bis mother's descendants. Besides the regulations for burials, the inscription ends with a closure stating that anyone who violated the burial regulations, should be considered criminally liable to punishment by several Lycian institutions and divinities.

Keywords: Lycia, ancient roads, Fethiye, Telmessos, Pinara, Tlos, Kadyanda, Araxa, Kalynda, Daidala, Lycian inscriptions, rockcut tomb, stele, cult, priest, sacrifice, altar, family tomb. 


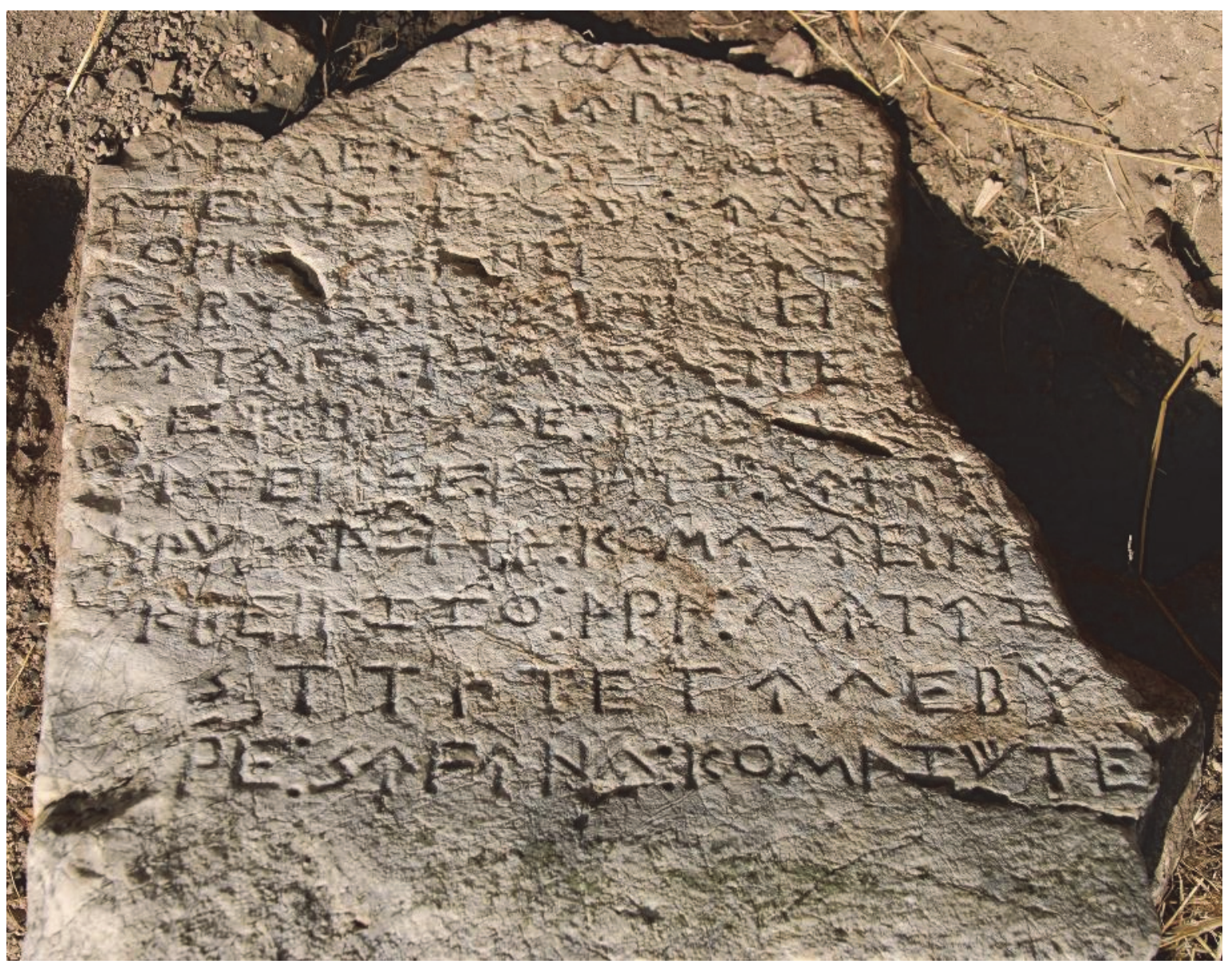

Fig. 42) Ins. No. 1 in Asarcık / Aloanda

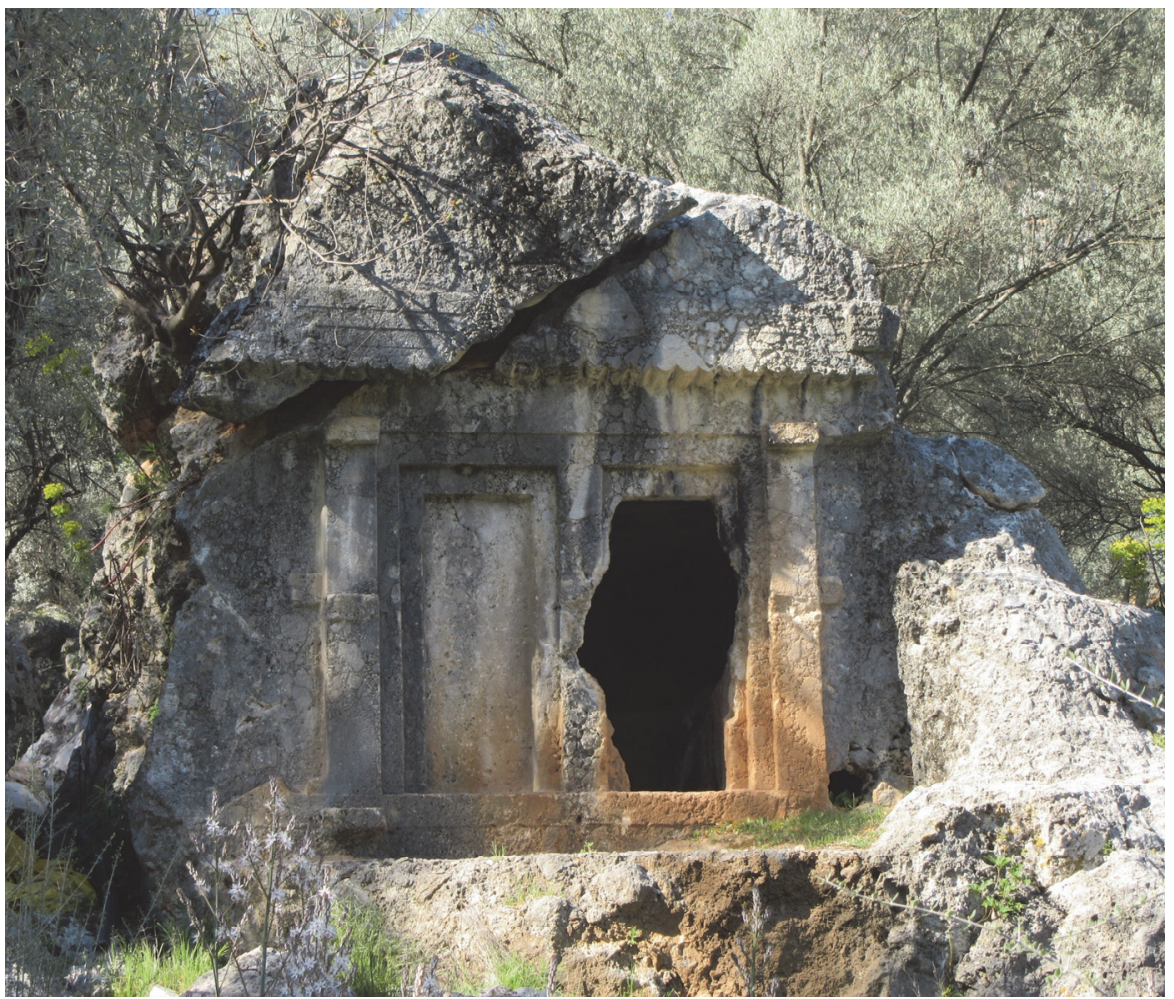

Fig. 43) The rock cut tomb in Sazak 


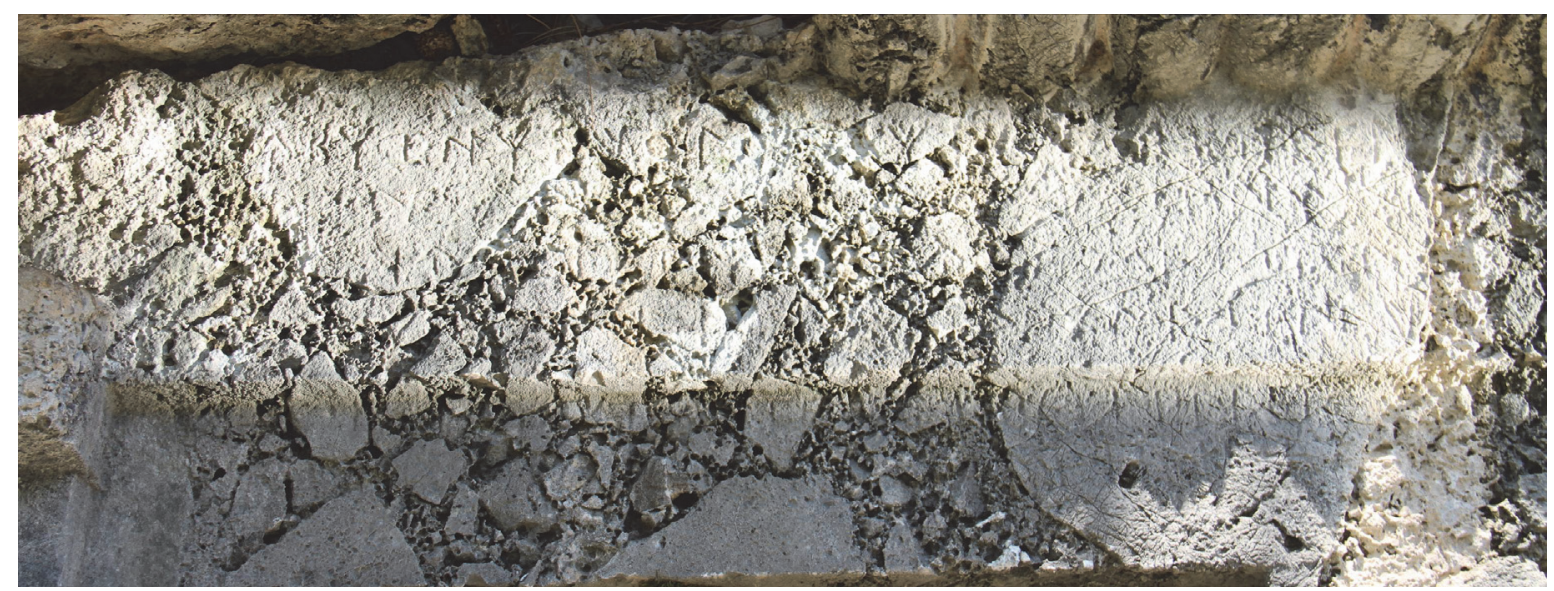

Fig. 44) Detail from the inscription on the rock cut tomb in Sazak

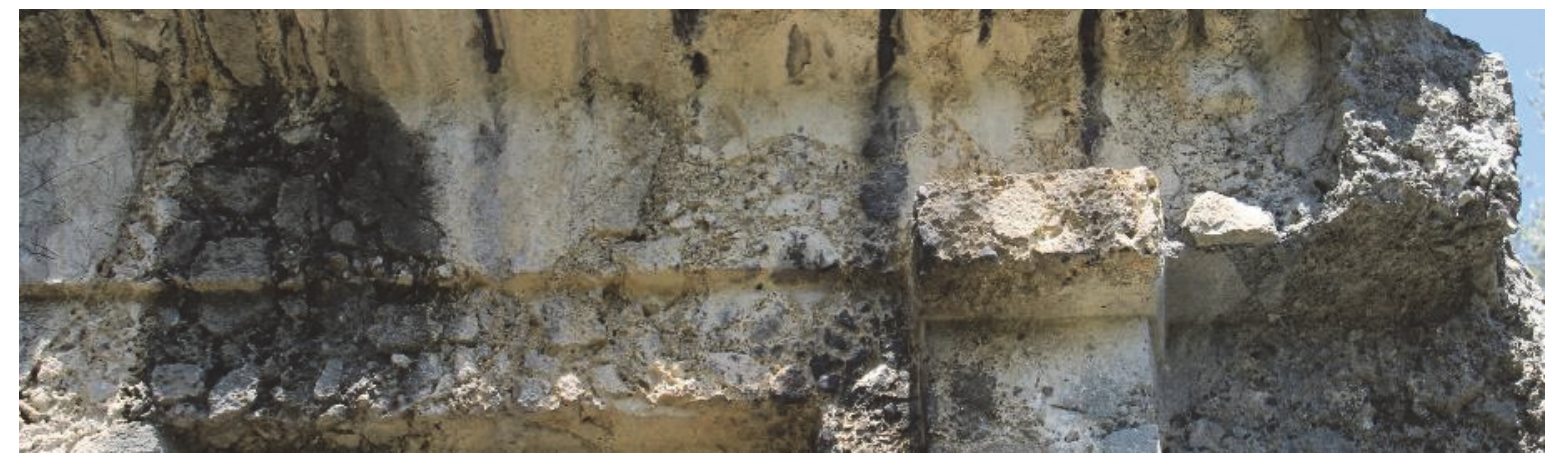

Fig. 45) Detail from the inscription on the rock cut tomb in Sazak

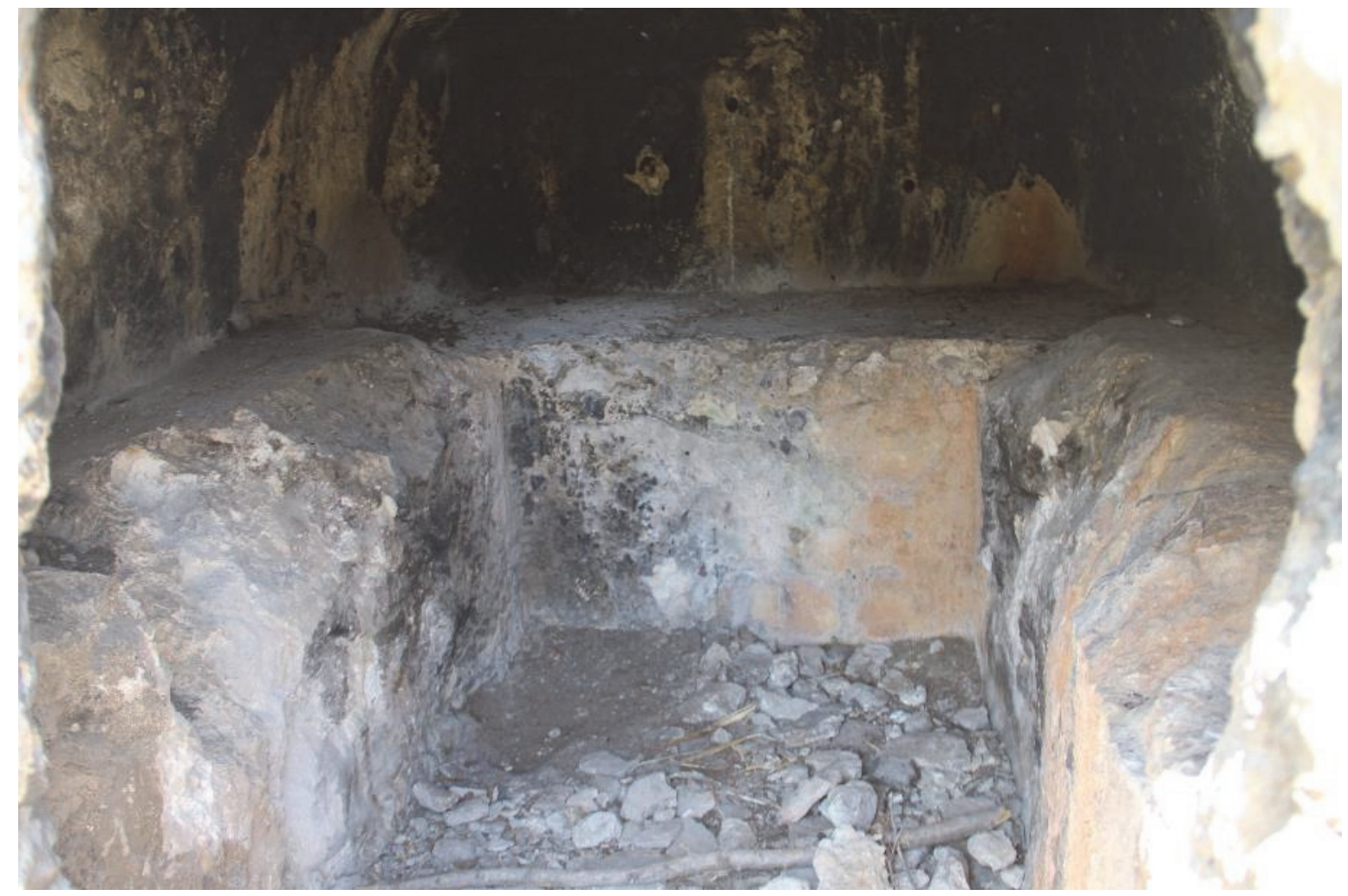

Fig. 46) Inside the rock cut tomb in Sazak 